GATEKEEPING AND UNPUBLISHING: HOW EDITORS MAKE PUBLISHING AND UNPUBLISHING DECISIONS

\author{
A Thesis \\ presented to \\ the Faculty of the Graduate School \\ at the University of Missouri-Columbia
}

\author{
In Partial Fulfillment \\ of the Requirements for the Degree \\ Masters of Arts
}

By NINA PANTIC

Dr. Tim Vos, Thesis Supervisor

MAY 2014 
The undersigned, appointed by the dean of the Graduate School, have examined the thesis entitled

\section{GATEKEEPING AND UNPUBLISHING: HOW EDITORS MAKE PUBLISHING AND UNPUBLISHING DECISIONS}

presented by Nina Pantic,

a candidate for the degree of Master of Journalism, and hereby certify that, in their opinion, it is worthy of acceptance.

Professor Sandy Davidson

Professor Richard Reuben

Professor Timothy Vos

Professor Margaret Walter 


\section{ACKNOWLEDGEMENTS}

Thanks to my committee for having the patience to persuade me into doing interviews, and consequently helping me to overcome my deep-rooted hatred of phone

interviews. I also want to thank Frank Russell and his editing class for spoon-feeding me this great topic. 


\section{TABLE OF CONTENTS}

ACKNOWLEDGEMENTS .................................................... ii

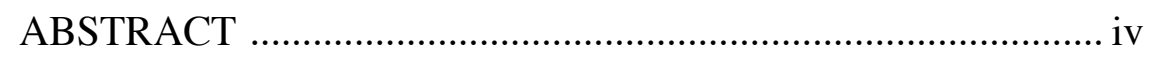

Chapter

1. INTRODUCTION .................................................... 1

2. LITERATURE REVIEW ..............................................

3. RESEARCH QUESTIONS .....................................20

4. METHODS ................................................................21

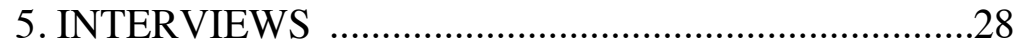

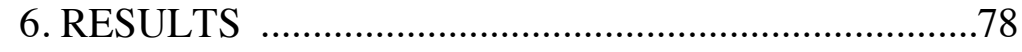

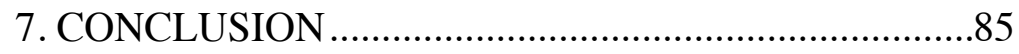

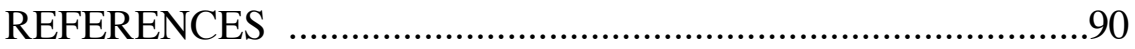




\title{
GATEKEEPING AND UNPUBLISHING: HOW EDITORS MAKE PUBLISHING AND UNPUBLISHING DECISIONS
}

\author{
Nina Pantic \\ Tim Vos, Thesis Supervisor
}

\begin{abstract}
Through in-depth interviews and qualitative analysis, this thesis studies decisionmaking within American newsrooms regarding the handling of unpublishing requests as well as the influences on editors' decision-making. The journalism industry does not currently have a standardized policy for dealing with unpublishing despite the fact that editors see cases on a regular basis. The problem is furthered by the fact that newspaper editors expect to receive more removal requests because of the shift toward more digital publishing. The research questions address how newspaper editors deal with unpublishing and what factors, including the threat of legal action, influence decisions to publish or unpublish. Gatekeeping theory includes multiple ways that editorial decisions are influenced by external factors, and the results of this study support that the law is one of the biggest influences.

It soon becomes apparent that the newspaper industry is very hesitant to remove anything that has already been published. The final results show that a reasonable solution is to include a statement acknowledging that the newspaper does not remove online stories except in extreme circumstances.
\end{abstract}




\section{INTRODUCTION}

Reporters in the United States operate within one of the freest press systems in the world, guaranteed by the protection from the First Amendment of the U.S. Constitution. According to Freedom House, the First Amendment "provides the core guarantee of press freedom and freedom of speech." Journalists are generally free to cover topics and report on anything, as The New York Times motto summarizes it, "without fear or favor." But total press freedom is complicated in a nation ruled by the Internet and filled with individuals that can take advantage of their own freedoms and rights to complain and make demands for content removal.

The purpose of this research study was to discover how editors deal with pressure and unpublishing requests, and how they react to controversial situations regarding published news articles. The outcome of the study provides input into what an industrywide standard of unpublishing could look like. For all further reference, unpublishing is the act of removing an article (or altering it severely by removing a large portion, removing the entire article temporarily, changing names or censoring some information) from the Internet after it has already been published.

Most newspapers do not have a clearly stated policy for unpublishing, and an industry-wide standard does not exist despite 78.2 percent of surveyed editors in North America saying that they would remove an article from the Internet if the situation arose (English, 2009, p. 4). Solutions do exist for dealing with published articles that set off 
lawsuits or angry readers, but a generalized policy is necessary in a time where Google searches can ruin a person's reputation and future. Since newspapers tend to have corrections policies, it seems only logical to have a policy for the biggest correction of all: unpublishing.

The study was completed by interviewing a number of American newspaper editors to find out three things: What their experience with unpublishing is, how they deal with liabilities involved in publishing, and how they would react to hypothetical scenarios involving certain published articles. A literature review shows that journalists faced lawsuits more often earlier in the 1900s before New York Times Co. v. Sullivan (1964). Defamation laws affected journalistic freedom and influenced the ongoing debate over what is more important: an individual's right to privacy or the public's right to know. The relationship between press freedom (i.e. the First Amendment) and journalists continues to change and grow, but four aspects of law highlight the relationship between media and law: defamation, negligence, indecency, and invasion of privacy.

Gatekeeping theory frames and constructs this study because the concept explains how and why information is passed through various gates before actually reaching the audience for mass consumption (Shoemaker \& Vos, 2009). While unpublishing is opposite in that it is the decision to remove information from the audience, it is still relevant to gatekeeping because the very same gatekeepers (editors, reporters, etc.) are making the decisions regarding both what to reveal (publish) and what to hide (unpublish). 


\section{LITERATURE REVIEW}

\section{Gatekeeping}

The theory that relates most to the concept of editors making decisions to remove content is gatekeeping theory. Gatekeeping is the process of publication and the way information from a news event passes through a number of gates and gets changed by the process (Shoemaker \& Vos, 2009). The theory can be applied just as much to the way the gate is moving backward to remove information, as is the case with unpublishing.

In gatekeeping, there are forces both in front and behind the gates, and the number, strength and polarity of the gates determines the amount of change in a message (Shoemaker \& Vos, 2009). Gatekeepers are one of the forces that can curtail the flow of information and also help information flow freely onward (Shoemaker \& Vos, 2009, p. 21). The process of media creation begins with raw news that is then collected by news gatherers (such as reporters) before turning into news copy. Then news processors (such as editors) go through the copy before publishing a completed product (Shoemaker \& Vos, 2009).

Enli's (2007) study looked at what characterizes the gatekeeper in the digital media age. She said that earlier studies were focused on individual journalists and editors (gatekeepers) but critics argue that choices do not take place in a vacuum "but are constrained by institutional factors such as editorial routines, journalistic culture, and market needs" (Enli, 2007, p. 49). 
According to Shoemaker and Vos (2009), there are a number of different levels of gatekeeping analysis, but two are relevant to this study: individual and social institution. Individual level of analysis is an individual gatekeeper as the force at the gate pushing information forward or holding it back (p. 48). The gatekeeper can experience secondguessing, where the information is not taken at face value and may be untruthful or not at the highest level of accuracy (p. 35). Decisions are made using cognitive, or judgment, heuristics, most related to common sense (p. 37). Shoemaker and Vos (2009) said, "Gatekeeping is similar to the consumer decision-making process because gatekeepers are consumers, producers, and distributors of messages" (p. 39). Cassidy (2006) explained that the individual level focuses on individual journalist factors such as "personal and professional background, attitudes, values, and beliefs" (p. 7).

The social institution level of analysis exists because community organizations operate inside a social system and coexist with other social institutions (Shoemaker \& Vos, 2009). The government is an example of an institution exerting pressure by applying laws, policies, and regulations to the media (p. 89). One of the pressures on gatekeeping is law, and Shoemaker and Vos (2009) said that libel law “... applies across the mass media and establishes a real possibility of a lawsuit should gatekeepers publish or transmit information that wrongly harms someone's reputation.” (p. 89) Roberts (2005) said that gatekeeping models have "become increasingly sophisticated as theorists consider wider ranges of the external pressures on gatekeepers and the internal characteristics of the individual gatekeepers and the system that employs them" (p. 2). Forces at the gate are naked power at the social institution level of analysis (p. 95). But clearly there are factors influencing gatekeeping decisions, such as the desire to publish, 
the belief in building the public archive with truthful, accurate information, and the pressure from extramedia institutions such as the law and the public.

\section{Legal environment for unpublishing}

Voakes (1999) described a model that explains seven social influences on a journalist's legal decisions: individual, small group, organization, competition, occupation, extramedia and law (p. 380). The most relevant influences to this study are individual because it is the personal background each journalist carries, organization because it is company policies and structural influences, and law (which is an extramedia influence). Voakes' (1999) argument is that because decision-makers choose content, it is logical that a hierarchy of influences affects gatekeepers' decisions dealing with content. The law is just one of many possible influences, and it is possible for the influences to be combined or to even come into conflict with one another (Voakes, 1999).

Voakes (1999) hypothesized that cognitive shortcuts such as social influences, including time constraints and peer norms, could be what has "short-circuited moral and legal considerations" (p.389). Furthermore, he found that ethical and legal distinctions seemed blurred oftentimes, and a journalist's good-faith efforts stemming off of facts and truth is morally defensible, and so they are also often legally defensible thanks to the First Amendment (Voakes, 1999).

Voakes (1999) referred to the Bezanson, et al. (1988) Iowa Libel Research Project that studies lawsuits in journalism. Voakes (1999) said his study shows only a small portion of the 1980's and 1990's invasion of privacy claims that had developed, but even though media defendants often win cases, the results can still be taxing psychologically and financially and can result in a "chilling effect" on future journalism efforts. He 
concludes that ignoring legal and ethical reasoning ruins journalism's opportunity to be more credible, responsible, and just. A background history of important cases can help explain how journalism and influence from legal pressures has developed over the years.

\section{New York Times Co. v. Sullivan}

The New York Times Co.v. Sullivan (1964) case can be considered one of the most important victories for journalism in history (Hodak, 2012). The case helped turn the tide for journalism, loosening the pressure on journalists who previously avoided stories and information that could potentially turn into lawsuits. Prior to New York Times Co.v. Sullivan, journalism faced libel lawsuits on a regular basis, and it was costing up to \$300 million (Hodak, 2012).

New York Times Co.v. Sullivan (1964) addressed whether or not the First Amendment protected newspapers from public officials attempting to sue for libelous damages (New York Times Co.v. Sullivan, 376 U.S. S. Ct. 254, 1964). It began when the New York Times ran the editorial advertisement "Heed Their Rising Voices" in 1960 created by the Committee to Defend Martin Luther King (Lewis, 1991, p. 6). The advertisement covered Montgomery, Ala., police officers abusing Southern black students. While not directly named, City Commissioner L.B. Sullivan sued the Times and demanded the removal of the advertisement, but the newspaper refused (New York Times Co.v. Sullivan, 376 U.S. S. Ct. 254, 1964). Sullivan sued The New York Times was charged for libel and the jury awarded Sullivan $\$ 500,000$. Sullivan's attorneys argued that, "The First Amendment of the U.S. Constitution does not protect libelous publications" (Lewis, 1991, 45). The case delivered a warning to other newspapers in that 
the Times had to travel thousands of miles and spend a lot of money to "answer for its offense," and other newspapers could face the same fate (Lewis, 1991, 34).

But the Times put in an appeal that eventually reached the Supreme Court, and justices voted 9-0 to reverse the decision (New York Times Co. v. Sullivan, 376 U.S. S. Ct. 254, 1964). The win gave journalists more freedom to report critically on public officials and other matters without as much fear of lawsuits. Edmonson (2011) produced a study that shows there were more Sullivan-like cases before and after the infamous 1964 case, and all of them played a role in the Supreme Court's "overhaul" of libel law (p. 28). Very early on, the court deemed most of what is now newsworthy as inappropriate for the public to consume and created a restriction on journalism in order to protect individuals from embarrassment as well as to occasionally protect the greater societal good of government processes (Gajda, 2012, p. 1762).

In New York Times Co.v. Sullivan (1964), the Supreme Court said that public officials could "recover damages when suing for defamatory statements relating to their official conduct" (376 US 254, 1964, p. 265). The damages were recoverable only if it were possible to prove that published statements were made with actual malice, meaning published with "knowledge that they were false or with reckless disregard of whether they were false or not" (New York Times Co.v. Sullivan, 376 US 254, 1964, p. 280). Proving actual malice by clear and convincing evidence is difficult in the court of law and could often be what ends up pushing the case in favor of journalism. The case was significant for saying that not only do you have to prove actual malice but by a now higher standard (New York Times Co. v. Sullivan, 376 US 254, 1964, p. 294). 


\section{Other important cases}

In White v. Nicholls, a customs collector sued an author for trying to tarnish his name by publishing a story (White v. Nicholls, 44 US 266, 11 L. Ed. 591, 1845). The Supreme Court ruled that the author used calculated force to try to make the customs collector "infamous, or odious, or ridiculous" and ruled it libelous (White v. Nicholls, 44

U.S. S. Ct. 266, 1845). In the1890 case Holden v. Minnesota, the Supreme Court decided journalists should not attend public executions and should not report anything outside of pure facts of who was involved and where it happened (Holden v. Minnesota, 137 U.S. S. Ct. 483,1890$)$.

There was also Patterson v. Colorado in which a journalist published an editorial cartoon making fun of the Colorado Supreme Court (Patterson v. Colorado, 205 US 454, 1907). The U.S. Supreme Court ruled that editorial "propriety and necessity" should have encouraged the journalist to not publish and ruled against the newspaper (Patterson $v$. Colorado, 205 U.S. S. Ct. 454, 1907). In the 1907 Patterson v. Colorado case, the Colorado Supreme Court cited another important news-related lawsuit (Gajda, 2012). In 1825, a lawsuit was filed in the Massachusetts Supreme Court against a local newspaper for publishing a story about a man who presumably died of alcohol poisoning at a local bar (Commonwealth v. Blanding, 20 Mass. 304, 3 Pick. 304, 1825). The lower court said the information was of "little relevance" and journalists should not have power to disturb families and friends should the embarrassing information be true, raising an invasion of privacy dilemma (Commonwealth v. Blanding, 20 Mass. 304, 3 Pick. 304, 1825). 
All of these cases prior to New York Times Co.v. Sullivan reveal a tougher time for freedom of the press, especially in cases involving published stories. Gajda (2012) said that Gandia v. Pettingill "turned the tide slightly in favor of newspapers and their editorial decisions regarding public officials" (p. 1769). In that case, a Puerto Rican newspaper published a critical article about a U.S. Attorney (Gandia v. Pettingill, 222 US 452, 32 S. Ct. 127, 56 L. Ed. 267, 1912). The attorney argued that the story was libelous, but the Supreme Court ruled that that the information was true and fairly reported. The Supreme Court ruled, "In the absence of express malice or excess, publication of actual facts is not libelous" (Gandia v. Pettingill, 222 US 452, S. Ct., 1912, p. 458).

In 1931, Near v. Minnesota finally moved decisions in favor of editor's sensibilities (Gajda, 2012, p. 1775). The court ruled in favor of publishers when it said that a Minnesota law violated the First Amendment for targeting newspapers that were "malicious" or "scandalous" (Near v. Minnesota, 283 U.S. 697, 703, 1931). The case was considered the first great press case (Lewis, 1991). According to Youm (2012), the First Amendment is the "oldest judicially interpreted free speech [constitutional] provision" (p. 1). It is also what makes the United States different than almost every other country in the world, granting journalists more press freedom. New York Times Co. v. Sullivan (1964) is still one of the biggest victories for free press. Edmonson (2011) said that was the moment the Supreme Court finally walked away from the common law tradition passed down from English courts to give the United States "constitutional protections of speech critical of the government, even speech that is false" (p. 28). 


\section{Defamation}

According to Black's Law Dictionary (2013), defamation is the taking from a person's reputation through an offense injuring character, fame, or reputation through false and malicious statements. Libel lawsuits address all consequences of defamation. Despite the protection granted to journalism from New York Times Co. v. Sullivan (1964), defamation still exists. According to Kenyon and Marjoribanks (2008), defamation law is meant to regulate publication of harmful materials, but it also reveals the tension over journalistic standards (pp. 373-375).

The United States' approach to defamation law is different from the United Kingdom or Australia's approach, mainly because of the "Sullivan rules" stemming from the monumental1964 case (Kenyon \& Marjoribanks, 2008, p. 376). Defamation was just outside of the United States' constitutional protection before 1964's New York Times Co. v. Sullivan (p. 377). The so-called "Sullivan rules" explain that plaintiffs must prove fault and injury, and that plaintiffs have the burden of proof to win a defamation lawsuit (Kenyon \& Marjoribanks, 2008, p. 377). Kenyon and Marjoribanks (2008) interviewed more than 170 journalists in the United States, United Kingdom, and Australia about defamation and journalism and found that many problems exist with the relationship between defamation law, public debate, and journalism (p. 378). Despite New York Times Co.v. Sullivan and the protection for journalism's free speech, defamation remains alive and well.

One theme found by Kenyon and Marjoribanks (2008) showed that journalists in all three countries are aware of the defamation law and say it affects their work by having a "chilling effect." The "chilling effect" means that journalists and editors will either not 
pursue stories or will pursue stories in a modified fashion, in certain circumstances, for fear of being liable under defamation law (p. 379). The effect is self-censorship because it is a way for journalists to stop themselves from publishing information. Kenyon and Marjoribanks' (2008) study also revealed that journalists are aware of certain individuals and institutions that are prepared to sue once written about, especially in the newspaper industry, and research has suggested that newspapers are more at risk for defamation lawsuits than other media outlets (Kenyon \& Marjoribanks, 2008, p. 379). The issue raised by risk of defamation lawsuits is an increase in self-censorship by newspapers and it can show that there is still fear surrounding publication.

To face libel lawsuits concerning public figures, journalists must publish something that is fact, not opinion, which is proven false and which they knew to be false, or had doubts over falsity and still published (Kenyon \& Marjoribanks, 2008, p. 380). Proving malice and intent to do harm is the more challenging part of the lawsuit. Youm (2012) said that the actual malice rule created by the U.S. Supreme Court in 1964 is "what makes U.S. law stand out from the rest of the world" (p. 1).

\section{Negligence}

Another legal issue facing journalism is negligence. Negligence, according to Black's Law Dictionary, is the accidental failure to exercise care in a way that a reasonable or prudent person would have done. In a negligence lawsuit, the person accuses the person or legal party that he or she failed to use reasonable caution or caused damage. According to the Digital Media Law Project, a plaintiff proves negligence by showing that the defendant did not show a reasonable amount of care in publishing a statement. 
One notorious case involving negligence and the media is Hyde v. City of Columbia (637 S.W. 2d 251, 1982). The plaintiff, Sandra Hyde, sued the city because the police department released her name and address to the press after she was abducted and kidnapped by an unidentified man (Hyde v. City of Columbia, 637 S.W. 2d 251, 1982). She escaped from her attacker but because of her personal information published first by the Columbia Daily Tribune and then by the Columbia Missourian, he was able to terrorize her on a number of later occasions, including showing up at her house. The pleadings showed that the Tribune, being the first to publish her name and address, failed to protect Hyde from foreseeable risk of physical harm, and she suffered from the threats from her still-at-large assailant. Negligence liability happens when a failure in duty results in damages, and while the newspaper's duty is not to protect persons from all harm and injury, it is supposed to prevent foreseeable physical damages (Hyde v. City of Columbia, 637 S.W. 2d 251, 1982, p. 256). The court ruled in favor of the Tribune, but the appeals court ruled in favor of Hyde, and the Supreme Court let the appeals ruling stand, proving that newspapers can be liable for exposing a person to unreasonable foreseeable danger even though it was public record and obtained legally under a Sunshine Law.

\section{Invasion of privacy}

Yet another possible liability is invasion of privacy, which, according to Voakes (1999) involves the "disclosure of private facts" via publication of "intimate, personal information" that is "highly offensive to a reasonable person" and not of "legitimate public concern" (p. 379). Voakes (1999) surveyed 42 journalists who have been sued for invasion of privacy and discovered that most were oblivious to possible legal trouble but 
did admit to noticing ethical issues. The study examined the decision-making process involved in newsgathering cases that involved invasion of privacy. A 1991 survey created by Gersh and the Society of Professional Journalists found that media outlets, including TV stations and newspapers, were becoming more sensitive to the privacy concerns of their audiences. The main topics were rape and murder victims, and eighty nine percent of news executives said that they would not agree with a family's request to withhold names of murder victims while 30 of 32 newspapers said they would not use rape victims' names. The Florida Star v. B.J.F involved a weekly newspaper releasing the name of a rape victim that was published by a local police department. The Supreme Court ruled that the police department would pay for damages but the First Amendment protected the newspaper (The Florida Star v. B.J.F., 491 U.S. S. Ct. 524, 1989).

In the invasion of privacy survey, media defendants won nearly ninety percent of cases (Voakes, 1999). The study's reflected the Bezanson, Cranberg and Soloski (1988) study of journalists and lawsuits that showed plaintiffs winning only twelve percent of non-appropriation privacy cases. Bezanson (1986) said the three researchers were specifically interested in why plaintiffs pursue lawsuits and what journalists can do to prevent lawsuits. The research study, titled the "Iowa Libel Research Project," coded libel and privacy cases between 1974 and 1984, as well as surveyed 170 newspapers to explore lawsuit, liability, and settlement rates. They discovered the plaintiff success rate in reported cases was 10 percent (Bezanson, 1986). The successful plaintiffs averaged $\$ 80,000$ in damages, most of which went to covering costs, and so Bezanson (1986) said the driving factor in pursuing lawsuits was not financial gain but restoring reputation, and suing in libel cases "represents a legitimation of their claims of falsehood" (p.791). The 
study shows that the plaintiffs tend to contact the media first before contacting lawyers, and the initial media response is often offensive, indifferent, arrogant, and/or insensitive, fueling the fire to sue (Bezanson, 1986). Regardless of the unlikelihood of winning cases and the lack of financial compensation, 67 of the 106 plaintiffs that lost cases claimed the lawsuit still accomplished something (Bezanson, 1986).

In regards to newspapers and invasion of privacy, Zelermyer (1959) said the "primary function of a newspaper is the dissemination of news" and "the public is entitled to information vital to the preservation and promotion of its rights and privileges." He adds that the public does not have a right to "view private affairs in which it has no legitimate interest" (p.113). Zelermyer also pointed out a distinct difference between right to privacy and right to freedom from defamation, stating that privacy deals with peace of mind while defamation deals with reputation, and so truth does not justify invasion of privacy.

Prosser (1960) was one of the first to write about torts and explained that the principles of tort law revolve around the common thread that the liability is based on conduct that is socially unreasonable. According to Prosser (1960), United States law has established four kinds of wrong related to the tort of invasion of privacy. The first is intruding into a plaintiff's private affairs (Prosser, 1960). The second is the public disclosure of embarrassing private facts about a plaintiff (Prosser, 1960). The third is publishing facts that place the plaintiff in a false light, and there must be publicity along with the publication, and the fourth is appropriation of the plaintiff's name for the defendant's benefit (Prosser, 1960). 


\section{Indecency}

Chamberlin, Lee and Middleton (2004) explained that obscenity has no First Amendment protection but indecent material does have some protection. While it is difficult to reach a consensus on which words and images are punishable under criminal law, the government does have the Indecent Displays (Controls) Act of 1981 (Crone, 2002). The act reads, "it is an offence for a person to display or cause or permit to display an indecent matter" (Crone, 2002, p. 209). Indecent matter is not defined, but it must be visible from a public place (Crone, 2002).

English (2009) collected one example of a complaint for unpublishing that dealt with indecency. Jana Collier, a staff member of the Dayton Daily, explained that a woman accidently uploaded a nude photo of herself in making additions to an online gallery and asked for it to be removed (English, 2009, p. 12). The newspaper complied with the request. The example seems straightforward and simple, as well as very literal, but it is possible for cases to be a lot less obvious.

A number of indecency cases involve broadcast. Federal Law and the FCC prohibited indecency on the radio and television from 6 a.m. to 10 p.m. and provided a definition of indecency as "language or material, that, in context, depicts or describes, in terms patently offensive as measured by contemporary community standards for the broadcast medium, sexual or excretory organs or activities" (FCC v. Fox Television Stations, Inc., 132 S. Ct. 2307, 2012, p. 2317).

In FCC v. CBS Corp., Justin Timberlake was performing "Rock Your Body" during the halftime show of the 2004 Super Bowl with Janet Jackson. During the song, he tore a part of her bustier, revealing her breast momentarily (FCC v. CBS Corp., $132 \mathrm{~S}$. 
Ct., p. 2678, 2012). The Federal Communications Commission (FCC) fined CBS $\$ 550,000$ but CBS did not have to pay because the FCC did not give enough notice of its change in policy. Justice Roberts said the FCC does not follow the fleeting expletive policy anymore, so in the future "wardrobe malfunctions" would not be protected (FCC v. CBS Corp., 132 S. Ct., 2012). The "fleeting expletive" policy had allowed a fleeting naughty word or act, but then the FCC switched to a "first blow" policy, where any moment of indecency became fineable (FCC v. CBS Corp., 132 S. Ct., 2012).

It seems that journalistic standards would be useful to guide journalists down the right path and away from all four of the above legal problems, and when ethical considerations come into play in a given situation, it seems logical for law to be right around the corner.

\section{Journalism standards}

Journalism's standards are an every day part of the newsroom. Journalists are taught to follow a code of standards early on. According to Kovach and Rosenstiel (2007), there are ten principles in journalism (p. 5). Journalism's first obligation is to the truth and its first loyalty is to the citizens (p. 5). It relies on verification, and journalists must maintain independence from those being covered (p. 5). Journalism must monitor power in order to serve as a watchdog, and provide a forum for public criticism, and it must try to be relevant and interesting (Kovach \& Rosenstiel, 2006, p. 5). Journalism must be comprehensive and not leave things out on purpose, and journalists must follow a moral compass of ethics (p. 6). These are just some of the standards present in the newsroom. 
Along with journalism's standards, there is recognition in the newspaper industry that journalists have a responsibility to protect the reputations of persons whose names are published in the newspaper (Kenyon \& Marjoribanks, 2008, p. 380). Gibeaut (1998) argued that the use of the word "allegedly" allows media to say anything, and sloppy reporting is spurred on by competition among media outlets in the race to be the first to make something public knowledge (p. 89). While there is a race to be the first to publish breaking news, journalists must still uphold a number of standards focused on accuracy, civility, truthfulness, and transparency in order to produce a legitimate, believable publication.

But journalistic standards also teach that news about private persons is not as interesting or newsworthy as news about public persons (Gajda, 2012, p. 1760). Courts and juries decide whether the public value of the news published is above the private or public individual's right to privacy (Gajda, 2012, p. 1760). The problem in that is there is not a clear line between the two constitutional principles: right to individual privacy and the right of press freedom (Gajda, 2012, p. 1761). The justice system's definition of newsworthiness has become more along the lines that news (or information that the public deserves to have) should be broadly construed and not only based on the public's need for information (Gajda, 2012, p. 1761).

According to the Society of Professional Journalists, journalists have an obligation to seek truth, minimize harm, act independently and be accountable. Journalists focus on collecting information and following journalism's principles, but they can still get into trouble (Kenyon \& Marjoribanks, 2008, p. 381). There's also that 
fact that news editors hold most of the power and responsibility for making publishing decisions, and they get to decide what news is appropriate and what is better not being published (Gajda, 2012, p. 1760).

\section{Unpublishing}

According to a pilot study by this study's researcher - titled "Should the Columbia Missourian have an Unpublishing Policy?" - newspaper editors face more and more complaints from readers and members of the public wishing for the removal of online stories (Pantic, 2013). But unpublishing is not recognized as an industry-wide standard, and often editors are faced with the decision of what to do without much guidance (Pantic, 2013). Sometimes it is easy for editors to silence the complainer by simply explaining it is not the newspaper's policy to remove stories, and sometimes editors actually remove stories, either permanently or temporarily (Pantic, 2013). The 2013 study found that some of these complaints have the ability to turn into lawsuits. Based on the actions editors are forced to take in these unpublishing situations, it is possible to look at the removal of online articles as a form of self-censorship and also as an act of gatekeeping.

English's 2009 study surveyed 110 newspapers in Canada and the United States. English (2009) found that requests for the removal of online stories have been increasing steadily. While many newspapers were found to have a general, newsroom wide known policy for removing content (unpublishing), not all of them had a written, public policy despite the majority (78.2 percent) of editors saying they would unpublish content (English, 2009, p. 5). English (2009) found that an industry standard simply does not exist. In her conclusion, she stated that journalists should unpublish for the right reasons 
in rare circumstances, and "in most cases, this would be for legal reasons, including defamatory material, material that is in contravention of a publication ban or other legal restrictions" (English, 2009, p.15).

\section{Internet age}

Information and news is being spread faster than ever before, and publishing content is possible with a simple click of a button or the tap of a finger. But the issue with online defamation is that someone can very easily post maliciously on the Internet and "redefine who you are" (Sanders \& Olsen, 2012, p. 355). While Sanders and Olsen (2012) discuss online comments and citizen journalist bloggers, the Internet has affected and changed journalism in unavoidable ways.

Roberts (2005) pointed out that gatekeeping theory has "gained new interest" because of the Internet making publishing easier without traditional gatekeeping. The Internet has affected censorship and gatekeeping, since anyone can publish anything at anytime from anywhere, and gatekeeping has had to adapt (Roberts, 2005). The change in technology further adds to how the issue of unpublishing has developed over the years. Roberts (2005) conducted an interview with Pamela J. Shoemaker in 2005, where she stated that gatekeeping is an important psychological process inside of every person (p. 14). When referring to the onslaught of the Internet age, Shoemaker said, "each time we come across a new media, we ask new questions that are really old questions" (Roberts, 2005, p. 14). Shoemaker's point is that gatekeeping is not fading away (p. 14).

\section{What's next?}

The literature shows that libel and invasion of privacy lawsuits tend to end in favor of journalists. It is important to acknowledge the boom of the Internet in this study 
since it examines publishing information online and deciding whether or not to remove it after publishing. The amount of press freedom in America is vast, and yet self-censorship still exists in some form by the very people creating and publishing the news and acting as gatekeepers. Newspapers have removed content or severely altered content after publication in order to appease readers or members of the public, but the more important issue is how unpublishing decisions are being made in newsrooms, how news editors respond to situations involving negligence, defamation, invasion of privacy and/or indecency, and what factors influence the decision to publish and unpublish.

But without industry-wide standards to help control the ways journalists decide on unpublishing, it is difficult for the issue to be entirely contained. Unpublishing happens, and so should standards for it, and this study will explore how editors deal with the topic of unpublishing and what possible solutions exist.

The research questions include:

$R Q$ 1. How do or how might American newspaper editors respond to and deal with unpublishing dilemmas?

RQ2: What factors, especially regarding pressure from possible legal action, influence decisions to publish or unpublish? 


\section{METHOD}

The study used qualitative methods to attain a deeper level of understanding and a richer description of the topic at hand in order to observe themes. Instead of analyzing numbers and surveys (which has been done before, see English, 2009), this study interviewed a number of American newspaper editors to find out what their experiences are with unpublishing and, just as importantly, how they would deal with possible scenarios that could lead to unpublishing or severe alteration.

Richie and Lewis (2003) said that in-depth or semi-structured interviews are main methods in qualitative research, and "personal accounts are seen as having a central importance in social research because of the power of language to illuminate meaning" (p. 138). One key feature of the in-depth interview is the ability to combine structure and flexibility (Richie \& Lewis, 2003). Bernard (1994) said that semi-structured or in-depth interviewing is scheduled, and while open-ended, it follows a general script and covers certain topics. He suggested using semi-structured interviewing when there likely will only be one opportunity to interview a subject, and that is the case in this study mostly because editors do not have a lot of spare time (Bernard, 1994). Another point made by Bernard (1994) is that this type of interview works best with "people accustomed to efficient use of their time" because there is control over what the interviewer wants to gain from the interview, but there is freedom from both ends to follow new leads as they come up (p. 212). 
The interviews used elicitation methods because they "have more of an exploratory or emergent character in their attempts to reveal tacit subjective understandings in some cultural domain" (Johnson \& Weller, 2001, p. 492). Johnson and Weller (2001) covered a number of elicitation interview examples, one of which involved a researcher trying to get an inside scoop of men on skid row because he was interested in a certain aspect of that particular lifestyle (p. 493). Similarly, this research will be asking editors to reveal inside information on how they make decisions within the newsroom regarding both real and hypothetical scenarios. Richie and Lewis (2003) said that one of the key features of in-depth interviewing is the use of probes and techniques to elicit deeper responses beyond the initial response by using follow-up questions to create explanatory evidence. Voakes (1999) did a similar study to examine the decision-making process by interviewing 42 journalists who were sued for invasion of privacy.

The questions were open-ended to answer "how" and "why" questions for indepth, rich answers. The interviews began with questions about the editor's background and professional experience for contextual value. The editors were also presented with four hypothetical scenarios based off of real cases that relate to unpublishing or severe alteration situations. The scenarios were created based on a pilot study orchestrated by the researcher (Pantic, 2013) along with English's (2009) study in which she asks her survey-takers to provide unpublishing cases and resolutions (p. 11).

One of the editors interviewed is Kathy English, a Toronto Star public editor more familiar with unpublishing than the rest of the interview subjects, and for that reason, she has not remained anonymous. English was able to provide greater insight and more 
information on the topic at hand, and that interview covered more areas of unpublishing, including questions about her 2009 study.

The semi-structured interviews included a set of questions to loosely guide the answers and conversation. The editors were not given the questions or scenarios beforehand but were all hearing them for the first time. The questions were:

1. What is your role in choosing what content gets published and what does not? (Who makes the final decision in publishing and changing published articles?)

2. Have you ever had to deal with a story that called for unpublishing or severe alteration (such as name changes, removing large sections, unpublishing a story temporarily, etc.)? If yes, how was the decision made? Did you consult with others? Was there protocol to follow?

3. Does your method (real or hypothetical) of dealing with unpublishing requests satisfy your newspaper staff and the complainer?

4. Do you work closely with a lawyer, or have a lawyer to consult with?

5. How aware are you and your staff of legal repercussions?

6. What is your course of action if there was a threat of a lawsuit associated with a published article?

7. What is your personal experience with liabilities and published stories?

8. How do outside pressures influence your publishing or unpublishing decisions? (What are some of these outside pressures?)

9. How would you respond to and deal with scenarios 1, 2, 3 and 4 ? 
Scenario 1: A local man is accused of assault and arrested, and the newspaper reports on the story based on a press release provided by the police department. A week later, the police discover that the alleged victim fabricated the story, and the case is expunged. The editor adds an update to the story online but the original arrest story is not removed, and online searches still connect the man's name to the arrest. He's complaining that it is negatively and unfairly affecting his reputation.

Scenario 2: A woman is involved in an alleged kidnapping incident in which she is convinced her life was in danger, but the police are still investigating the case. The police release both her name and address in a press release, and your newspaper publishes a story including that information. She sues the city, your newspaper and the reporter for negligence for putting her in foreseeable harm after the assailant stalks and threatens her outside her house.

Scenario 3: A minor with a medical condition is described in detail in a story. The reporter interviews his friends and family to cover both the condition in general and use him as an example. Ten years later, the now-adult minor requests the story be removed or changed because he no longer suffers from the condition and he never consented to be included in the story. It is affecting his reputation and his ability to get a job.

Scenario 4: Your newspaper prints an article about an important speech, and one of the quotes includes an offensive swear word. In the editing process, the offensive word is accidently left uncensored, remaining on the website for hours as well as being published in the print paper. Readers are outraged and complaints flow in. 


\section{Study Samples}

The criteria for the interviewees included a number of factors. The sample was 10 editors who currently work for or recently worked for newspapers in the United States. The circulation size of the newspapers varies greatly from approximately 50,000 to nearly 2.5 million with most newspapers falling within a 150,000 to 400,000 range (see Appendix C). The range of editorial experience ranges from one year to over 30 with half of the sample holding over ten years. The newspapers all produce online content. While the topic is unpublishing, the editor did not need to have had first-hand experience removing an article to qualify.

The recruitment was done via email to introduce the study and the expectations of the interviewee candidate, and care was taken to pursue editors in all parts of the nation by avoiding selecting multiple editors from a single state. The researcher used the recruitment letter listed in Appendix A and contacted editors via email using contact information pulled from the newspapers' websites. A pilot study was conducted in spring 2013 with four editors, and the questions in this study are far more in-depth, as well as include hypothetical scenarios instead of solely asking the editor to produce examples of unpublishing. The editors' names will remain anonymous for the purpose of preserving the research results, and each editor was notified of that fact as well as the purpose of the study before the interview began. The interviews were conducted via phone and Skype for a roughly estimated time of 30 to 60 minutes. Every interview was recorded using a recording device for the purpose of post-interview transcription, and the interviewees were notified of the recording beforehand. Bernard (1994) suggested recording semistructured interviews and being cautious of interviewees' sensitivity to discussing certain 
topics on tape. This study aimed to be as transparent as possible, and the editors chosen knew what they would be discussing and for what purpose.

\section{Analysis}

This study used the constant comparative method to create codes in order to analyze information. The constant comparative method allowed the data to be broken down into "incidents" (Glaser and Strauss, 1967). Lincoln and Guba (1985) described four stages of the method: comparing incidents in every category, incorporating categories and properties, delimiting the theory, and writing theory (p.339). This study does not write a theory from analyzing the interview transcriptions but does refer to and use gatekeeping theory to provide a framework to explain how unpublishing decisions are made.

Coding is a part of the constant comparative method of qualitative research and is used in this study. Open-coding is the initial organization of data, and the process began with data collection (Given, 2008). The goal was to break down the results into smaller segments and be able to connect codes into categories and then eventually connect categories into themes. According to Given (2008), researchers can make as many names, definitions, and codes as needed in the initial open coding process. Furthermore, any phenomena can be classified and coded more than one time (Given, 2008).

After open coding, the next step was using axial coding to confirm the codes already created by re-reading texts and to find out how the concepts are related (Given, 2008). The idea was to relate the concepts into larger categories. To do this the researcher dissected the information thoroughly to find out the properties and dimensions of the 
categories. As categories emerge, the researcher asked more questions in order to focus the categories even further (Given, 2008).

The final phase of analysis was selective coding. In this stage, explanations of the phenomena emerged after the linking or integrating of categories to develop stories (Given, 2008). Given (2008) explained that, "the choice of the core category and the explanation provided is the researcher's interpretation of what is happening," and there is more than one possible interpretation of data.

The goal of coding was to come up with themes and explanations of the categories and concepts that come up within the text. Gorden (1992) said that coding categories have two characteristics: all-inclusive or mutually exclusive. "All-inclusive" means the range includes response categories that are relevant in a certain dimension while "mutually exclusive" means the category is in a clearly defined dimension that cannot fit into two categories simultaneously.

After the coding process, strong categories emerged that help explain the phenomena of what kinds of situations newspaper editors face and how they make decisions regarding articles that could result in defamation, negligence, indecency and/or invasion of privacy. The goal was to extract information from the interviews to help explain how both publication and unpublishing decisions are influenced. This study uses interviews and incorporates gatekeeping theory to make steps forward in developing an unpublishing standard for the journalism industry. 


\section{INTERVIEWS}

\section{Experience with unpublishing}

One of the first questions asked at the beginning of interviews with editors was whether or not they have ever actually had to remove a story after online publication. The collection of answers is a mixed bag of both yes's and no's. A few editors immediately jumped into explanations of how they would make corrections and how the correcting process would occur instead of addressing any removal of the story. Editor 1 has been working over a year and half at a newspaper and he said they had never removed a story during his time and, not only that, but he had never removed anything during his lengthy experience as a journalist:

The beauty of the web is you know you put it up there and people read it and they call and say well that's not exactly right. I've never had an issue where we've had to completely redo a story or had anything like that happen, not in the time that I've been here.

Editor 4 has an ethics and standards editorial role at her newspaper. She said she often asked more questions and demanded more information from the reporter for clarification before publishing but rarely is a story removed: 
In terms of removing content or changing content, again after we go through this forensics process, and consort with our First Amendment lawyers if necessary, we decide what's the right path to take, and it's very seldom that content will be removed from the website.

So it is seldom done but the possibility to remove a story does exist both in her mind and in the newspaper's newsroom.

Another way of answering was to refer to standards for reporting and posting, as if the newspaper would never be in the situation where a mistake was large enough or a scenario was unique enough for content removal. Editor 3 said he had never taken a story down permanently, at least partly because the newspaper has "some pretty good standards for posting [online]." This way of answering masked the problem of unpublishing by using preventative rationalization. In saying that the newspaper's policies are good enough to prevent any need for content removal, a newspaper is saying it do not make mistakes and the issue of unpublishing is irrelevant. But since it has been known to happen, unpublishing is a relevant topic in journalism.

Editor 6 said they have never removed an article and justified it with, "Part of our thinking on this is that it's never possible to really, completely unpublish something online. There's ways around that and ways to find content even if we were to take that off our site." Editor 7 had a similar way of justifying the lack of unpublishing at his newspaper, a place he had worked at for more than a decade. He said there were stories that required substantial editing but cannot recall a case of removal, and added that the 
content would never be gone anyway in a world of Google and cached websites. He said, "If somebody really wants to find it, quite frankly they can find it. So really removing something from the site has some limited impact."

Editor 8 was strongly opposed to the entire concept of unpublishing. While he said that you have to have some sympathy depending on the circumstance, the concept makes him "queasy," and despite feeling sympathetic in some circumstances, he said, "I think overall it's a dangerous thing."

Editor 9 was also very strongly opposed to removing published content. He did outline a very specific example of a request and said it was the only request he directly had to deal with in close to 30 years at his newspaper. He was adamant that he was open to hearing requests, and willing to make appropriate corrections and even apologies, but he's "not removing it from the record because it happened." He rationalized that you cannot change what happened and you "can't ignore it" or "wish it away." In any case:

If you get it wrong, you can correct it and all these other things.

But to remove it, you're saying that on such and such day, this happened

but we're not going to record it, we're going to remove it from that record.

From a policy perspective, you're just asking for trouble.

\section{Scenarios}

The introduction of the four scenarios came up differently in every interview and included some variations, especially with regard to Scenario 4 (the case of offensive or indecent content). Editors were dismissing that scenario too quickly early on in the interviewing process, so it was adjusted to include any offensive statement or term that 
either accidently or deliberately was included and could include anything from curse words to racism and sexual content to gruesome crime scene descriptions or photographs.

\section{Scenario 1}

A local man is accused of assault and arrested, and the newspaper reports on the story based on a press release provided by the police department. A week later, the police discover that the alleged victim fabricated the story, and the case is expunged. The editor adds an update to the story online but the original arrest story is not removed, and online searches still connect the man's name to the arrest. He's complaining that it is negatively and unfairly affecting his reputation.

The most common solution for dealing with Scenario 1 was to attach a note to the original story and/or publish a follow-up story detailing what happened after the initial arrest. None of the editors said they would remove the story, despite the fact that the alleged criminal was entirely innocent. Editor 1 said he would keep it up as long as the addition to the story maintained accuracy:

If, basically, someone is saying, if you search for me on Google, this comes up that I did this or that, but if it also comes up that the charge was dropped, then I think that's fair representation of what happened because you were arrested and later the charge was dropped. The story is fine as long as it reflects reality.

Editor 2 had a softer response and said "maybe," but he did have his own personal example of a completely false story published about him regarding the firing of an employee. He said unpublishing is case by case, and so it is difficult to say exactly what would be done, but it is not that helpful to remove the story since these articles remain on the Internet forever regardless. He also mentioned the historical record since this arrest 
already happened and it was accurate at the time, despite turning out to be unfair and wrongful.

Just like Editor 1, Editor 7 said he would publish a second story to make the overall story accurate. While he said he would consider taking the story down, he said that the newspaper has to be careful since there may be a lot of stories going back and forth until the "ultimate truth" is reached, and then you cannot go back and remove 30 previous stories (or any number of previous stories). Just like Editor 2, Editor 9 said it was important not to revise history but just say what happened on what day. She said the newspaper had an obligation to run a story about dropped charges if someone was falsely accused and to run the story with as much equal play as the original as possible. English used an example of a law student arguing for the removal of a story that connected him wrongly to a crime. She said she would deal with Scenario 1 in the same way as Editor 9 by adding a follow-up and linking the two stories together. She added, "But we'd be very sure that in the top of that story in bold print it would state that all charges of so and so were dropped one week after they were charged." She argued that the arrest still happened, regardless of whether it was wrong and unfair or not. Editor 3 also stressed the importance of running the follow-up story just as prominently as the original. He would leave the original story since it was accurate at that point in time.

But Editor 6 had a different approach to this scenario. While she did say they would add a follow-up story, she said that the newsroom's practice is to not publish the name of someone who has been arrested until a charge has taken place. She said, "We don't think it's good enough to just get arrested to get your name in the paper and that's how we avoid so much of that [complaints].” In one example, she chose to not run the 
name of a suicide because the man was not really a public figure, and while broadcast stations used his name, the newspaper was content not doing so. Editor 6 said that not using of name until a person has been charged has helped save the newsroom a lot of time and prevented a number of complaints and requests from coming in.

\section{Scenario 2}

A woman is involved in an alleged kidnapping incident in which she is convinced her life was in danger, but the police are still investigating the case. The police release both her name and address in a press release, and your newspaper publishes a story including that information. She sues the city, your newspaper and the reporter for negligence for putting her in foreseeable harm after the assailant stalks and threatens her outside her house.

A real case similar to Scenario 2 is the Florida Star case, a case that Editor 8 referred to immediately. In The Florida Star v. B.J.F., a rape victim suing a newspaper for damages after it published her name from a police report (491 U.S. 524, 1989). On appeal, the Supreme Court ruled that suing for damages over public information would violate the First Amendment. The reporter who published her full name was actually in violation of The Florida Star's policy to not identify rape victims. Editor 8 said the case revolved around negligence and pinpointing who was really to blame. He said both the police department and the newspaper made the mistake, and while a lot of cases have been attempted on negligence against newspapers, he thinks that few have had great success.

Most of the editors said they would not run the names of a victim involved in a kidnapping (or other act of harm/violence). Editor 1 said the victim would have no case since it was the police department's fault for naming her in the first place, and it would be unlikely that his staff would name her to begin with. One rule, or practice in his 
newsroom is to not name victims in incidents such as domestic violence or rape even if the attackers know who they are and where they live. But this response drifted away from the scenario since the case clearly states that the name was used. The editor's reluctance to agree with being able to make such a mistake limited the value of his response.

Editor 7 said it might be an issue of fairness and invasion of privacy so the story may get rewritten if the name was published. Editor 2 argued that if the story has been picked up and made very public then it would not help to remove just the one story. Another editor reiterated that same idea when he said that in this day and age it is likely that 20 other newspapers have reported the same story as well (Editor 7). He cited an example where an article reported that a Utah man kidnapped some kids but the man was actually from Detroit. Another example he referred to was the Boston marathon where a New York newspaper put up photos of the wrong people as suspects. He said we might consider taking a story or photo down if it is "embarrassingly inaccurate," but you will never have 100 percent success with removal since it will live on in the digital world.

A number of editors said that if the person was high profile or a public figure, they would name her, or if the story had already gained national attention. Overall, editors were opposed to removing the name or story, and most often referred to the amount of media attention and whether or not the victim was a well-known person or whether the story itself was turning into huge news.

Some editors did manage to accept the scenario just as it was created, and one even had an example. Editor 4 referred to a case where the newspaper named a World Bank employee who raped a hotel maid but she said they did not use her name until much later on (which is when the story was gaining more media attention). 
But issues of personal safety were also a strong factor. Editor 6 said that when there are issues of personal safety and livelihood, "then we start asking questions among ourselves about whether or not we don't name them." Along the similar line of thinking was Editor 7 who said, "If you feel, as an editor, you're putting somebody's life in danger, you probably would do everything you can to help that person." English was one of the only ones who said that if the woman was in any danger, the name would be removed.

\section{Scenario 3}

A minor with a medical condition is described in detail in a story in which the reporter interviews his friends and family to cover both the condition in general and use him as an example. Ten years later, the now-adult minor requests the story be removed or changed because he no longer suffers from the condition and he never consented to be included in the story. It is affecting his reputation and his ability to get a job.

Again, the majority of editors did not want to take the story down, and most also did not want to make any changes or alter the teenager's name at all. Editor 1 said that the parents were to blame and they were the ones that gave consent on behalf of the teenager so there is no case against the newspaper. He said the story would not be written if the teenager did not get interviewed or the parents did not give permission. Editor 7 said he hoped that the story was done discreetly enough to not "out" the teenager but if the parents were quoted, then the youth is exposed. He said that if it were published with the name, removing it would not help much since it would already be all over the Internet. He said, "Just because you take it down doesn't mean Google is taking it down," which is not entirely true since the Webmaster removed the story from the website. Therefore, it can be removed from Google, but he could argue that other websites have picked up the story or computers have it cached. 
But the main argument was that the original story was as fair as possible so there is no sense taking it down since it is already out there. Editor 7 cited an example where his newspaper wrote a really bad restaurant review but a few years down the road the same restaurant turned things around and became hugely popular. He said the newspaper could not just simply take down the first review and replace it.

One of the few who said they possibly would take the story down was Editor 2. He said there would likely be a "vigorous debate" and there is a chance he would take it down especially if the story did not have any great news value to it, like if it was simply a feature story. But he said it is hard to just say yes or no since there are so many details and facts involved in each case.

The majority of the editors said they would not remove the story and they would not even change it. One editor simply said they would not take it down because they just do not do that. Another agreed and said they would not even change it, especially if they did try to talk to the teenager in the original story (even though she said leaving it up would break her heart). English was not sure how she would handle it but referred to an example. Someone was interviewed for having a gambling addiction and then a few months later he retracted his statements and said he lied about it. After the newspaper received a letter from his psychiatrist, The Star removed the story.

\section{Scenario 4}

Your newspaper posts an article about an important speech, and one of the quotes includes an offensive swear word. In the editing process, the offensive word is accidently left uncensored, remaining on the website for hours as well as being published in the print paper. Readers are outraged and complaints flow in. [Several variations of this were offered to interviews to be more general and cover more possible offensive situations.\} 
The majority of editors said that if a curse word got published unnoticed it would simply be edited out and it would be really unlikely to happen since so many eyes read through each story. English said they would make the removal or correction and add a note explaining that it violated the newspaper's policy. Editor 2 said that anything potentially offensive would be talked about long before it got published and a discussion would be had over its newsworthiness compared to the possible criticism and repercussion. He said that recently the newspaper published a story about an artist who painted naked people with body paint, one of which was pregnant. The news staff thought the story could offend people, but it did not cause very many complaints. He said it is also possible to post something accidently since the digital age has seen a huge increase in the number of online postings. Again, like in Scenario 2, editors tended to claim their newspaper would never let something blatantly offensive or as simple as a curse word end up online, which did limit the depth of answers.

Editors agreed that some stories do often offend readers despite precautions and that is just part of reporting, not the newspaper trying to be insensitive on purpose. Editor 3 said the newsroom rule is that the curse word or offensive statement needs to earn his permission before being published and he approves it depending on context. Editor 4 said her newspaper could do a follow-up blog post about the reaction to the story and gave an example of an ongoing defamation case in Hong Kong that was started when a story called a public figure "foul-mouthed." In a similar example, Editor 5 said he used the word "dumbass" in an editorial story and got a couple of calls with complaints. But when it comes to removal, he said, "To me, the accuracy of our archives and of our reporting 
on any given day is the paramount consideration, and the bar is set very high to surpass that."

Editor 6 said this issue comes up in the coverage of crimes but the goal is to give enough information without putting any salacious details in just for "the sake of being salacious." She said, "Let's have some respect for people as well, that's the line we try to walk there." Editor 7 said they would not remove anything but could do re-writing if it really comes off as sexist, racist or too sexually explicit. He also listed crime stories as a common example and said that sometimes the story will come with a warning attached especially if it includes a dead body or something along those lines. He said, "If, on purpose, you knew you were going to write something that's going to offend people, ultimately you live with it."

Editor 8 said it is difficult to clearly define what offensive is. He said, "Different people have dramatically different views on what's offensive," and, "you could argue that a report of anybody having committed a criminal offense is offensive." He added that the Supreme Court has made it very clear that speech cannot be banned, regulated, or punished for being offensive.

Editor 9 felt that if the story was "egregious" enough, then there could be a clarification or apology published. He said, "[they] publish something offensive to one group or another, and when covering news that's going to happen.” He gave an example of how the newspaper published a story about a Danish cartoon that defended Muslims right after 9/11, and since there was a lot of hostility against Muslims at the time, the paper chose not to publish the cartoon with the story. He said, "In a situation like that, you've got one group, you're going to offend somebody, you're always going to offend 
somebody. Somebody is going to find something in your newspaper every single day that they find offensive."

Overall, editors were not open to removing a story just because it was offensive since it is hard to tell what will offend someone and people can be offended by anything, but they were open to placing warnings, removing a curse word that appeared accidently, and discussing possibly offensive situations before publishing.

\section{Examples of unpublishing}

A number of editors had some direct experience with unpublishing and could give cases where they did end up removing a published story. The scenarios showed that editors are generally reluctant to allow for the removal of online content. While those four cases are not able to cover all possible situations, they did help facilitate conversation and lead to examples of real unpublishing. Despite almost all of the editors being hesitant to remove and giving reasons and excuses to not remove, it became apparent early on that removal does occur regardless of all the standards, practices, and precautions in place.

Editor 2 described an example of unpublishing involving a series on the influence of drug cartels that used a court filing naming a story subject as the informant. An attorney called the newspaper and said he would not have added the subject's name if he knew the media would run it, and since his client has already experienced a family member's murder from the drug wars, the inclusion of his name in the media endangered his life. Editor 2 said that after some discussion the article was removed with "an abundance of caution." 
Editor 4 said that online story removal has occurred under her watch:

So one of the issues I think that we face a lot of times, and I think it's more of a pressure now because I think we're trying so hard to get so much content out so quickly on so many platforms. It's so very different than it was 10 years ago when we read like five stories a day and now we're just really, really busy all the time.

She described an example involving a photograph accused of putting a kayaking company in false light. The photograph published was actually accurate but created an "unfair or untruthful connection in the reader's mind." The photograph was of a kayaker on an urban body of water published to go with a story about how a kayaking company was not prepared to deal with a storm during a trip that resulted in injuries and deaths. The problem was that the kayaking company in the photograph had nothing to do with the accident and argued the publication of the photograph was unfair and false light to use it because it connects the innocent company to negligence and the insufficiently trained staff of the other company. Editor 4 took the photograph down.

The kayaking photo case had a strong, compelling argument regarding false light. Another example provided by a different editor showed an argument for a subject's safety. Editor 5 said he only removed something one time and it was a marriage announcement. A notice of marriage came in, which he thought (but could not remember precisely) was from the Army, and it involved one member of a couple that was assigned to Afghanistan. The other member of the couple requested the removal by arguing it was 
putting this person in harm's way by revealing the location of the assignment. Editor 5 said, "We take all these requests seriously, and we send a note back saying we normally don't do this, why should we do it in this case?" The "heartfelt plea" involved a national security issue, and he rationalized, "Who are we to fight something like this?" and removed it.

Putting people in harms' way and facilitating a threat of danger are strong influences for removing stories. English said the Toronto Star has removed stories, most often for legal reasons, but they reject requests approximately 90 percent of the time. She listed one example involving a photograph of a woman from Afghanistan. The woman was going to school in Canada, and she was dressed in a hijab. Her family was receiving threats from the Taliban, and the Toronto Star removed the photo because it "felt that there was a legitimate physical danger to her family."

Editor 3 cited a recent example that was only a temporary removal to make corrections and changes. He said that because the story was written over the weekend, when inexperienced staffers were in charge. He said, "So when I saw it online while I was at home, I asked the people to take it down and fix it, and then put it back up." The story was not long and involved a man giving himself up to the police saying he stabbed his wife. Editor 3 felt the story was "poorly done" and it was only published for 15 to 20 minutes when he instructed whomever put it up to take it down and fix it. While that does not constitute a complete unpublishing, it still involved the removal of an article. 
Editor 4 brought up an example of a different kind. Recently, her newspaper did a story about a company's earnings and got it wrong. It reported that the company was up 85 percent when it was actually down. Before its current correction policy was in place, the reporter or editor could just go in and make the change without acknowledging it, and so that is what happened. Editor 4 imagined a broker convinced a client to invest $\$ 150,000$ in that company's stocks only to see the numbers go down instead of up, and then try to show the client where he read the erroneous information not be able to find it. Editor 4 said that means the newspaper was at fault, and put the broker in a very bad place. This error and hypothetical consequence was a key moment (despite not knowing if anyone really lost any money) because the example showed that if the newspaper publishes an error, it is important to admit the error clearly and not just cover it up.

\section{Handling requests}

While not every editor has removed an article, every single one has seen requests come in either from sources or readers. The majority of requests are turned away either by saying it is not an option to remove, referring to the policy (if there is one in place) or by offering corrections. Editor 9 described a request from a woman who had been profiled in a story that included her address. The woman was wealthy, and she was worried that the inclusion of her home address would invite kidnappers to steal her children on their way to and from school. Editor 9 admitted that he did not think the likelihood was high but still could understand her concern and did not simply dismiss it. But, he said no "because when you start down that road, it's fraught with peril. You really can't change what appeared in the newspaper because the newspaper is basically 
your historical record, and it happened that day, it appeared that day." He added that if there were factual errors, then a correction would be made.

Editor 7 said that requests are sometimes people wanting something removed from 10 years ago like, for example, a story that described a teacher getting fired and now he or she is applying for a new job and wanted the old story removed. Editor 7 said requests like that were made often but the newsroom would reply with: "We're really sorry, but we cannot remove something like that from our site. It's not appropriate. There was nothing unfair or inaccurate in that story." He added that a "surprising number" of requests were "no-brainers," meaning it was easy to say no, especially if somebody was simply embarrassed about something from years ago. When asked how many requests for removal he gets, Editor 7 said "not that much" and estimated approximately 12 per year or one a month. A select few of those would be looked at seriously while eight to eleven of them would be no brainers that are answered with, "Sorry, we can't do that."

According to English, the Toronto Star receives at least a couple times a month. As the public editor, she is in charge of all the requests, and she field calls from readers and sources concerning corrections, accuracy, and fairness issues. English's method of handling requests is straightforward because The Star has a policy and usually updates a story before looking into removing it. She explains the policy and why she cannot fulfill the request. She asks for any documentation that may be required and sets up further calls, as well as discusses the case with a number of people within the newsroom if the request has any merit. She said there is not a lot of arguing against the policy aside from some begging, and "it can be very difficult because people can make very personal cases 
why they don't want this content up there." One of the reasons she did her study on unpublishing was because she was really torn by the cases she was dealing with and it brought up the conflict between doing journalism and inflicting harm. She said sometimes people contact her over and over again and threaten legal action or even bring lawyers in, but no lawsuit has ever actually occurred, which she thought was because lawyers are saying there is not a legal case for unpublishing.

Editor 1 said that complaints usually reach him first and then head up to audience development staffers and associate editors. Sometimes lawyers are asked to make a decision, but the rule is "if the story was accurate when it was posted, it stays posted. If something was inaccurate, [they] run a correction and post that with the story." When asked to imagine any situation at all that could be a reason to unpublish, Editor 8 said if someone made a terrible mistake as a teenager and it is 30 years later and they have since then straightened up. The old article still comes up so it could look like an invasion of privacy. He said, "It seems like it might be something that inflicts emotional distress on somebody and, in most cases, may tangibly even cost them some kind of position." But he was not entirely certain he would remove anything regardless.

Editor 4 is a standards editor and especially interested in ethics and standards, and plays a very large role in dealing with requests (in a group along with four others who work for not only the newspaper but all the branded companies as well). He said complaints come in when something is wrong or if someone thinks a story is unfair or has loaded language. Requests come in once or twice a month, and the newspaper will not make changes unless there are questions about accuracy or fairness. Each one is its own 
case, and sometimes complainers call in to say they never said something in a story that is now years and years old. She said, "I think sometimes people talk to reporters, and then they have speakers regret later when they realize that the story is up online." Reporters are required to make clear that they are working on a story, and they have to use their real names so there is no confusion or uncertainty. She said that while a lot of stories are about people that are media savvy and great at manipulation, a number of people are not and will be in stories on unemployment or house foreclosure (for example) and not realize the consequences of giving information that will be in a story. The best way the newspaper deals with this is by making sure the sources are aware that their names and quotes will be used even if it may end up losing the reporter some sources and cost the story great quotes:

Somebody's just not that sophisticated and you put something in the [newspaper] and 2 million people in print read it and God how many online when it starts zooming around the Internet. I just don't think it's our job to ruin lives, unless they deserve to be ruined.

When it comes to the decision-making process, Editor 4's newspaper has a group especially for the purpose of handling complaints and concerns. The group teaches ethics and standards, and travels to teach, paying attention to United States laws and standards as well as international laws (if they apply). The group also does final readings on stories that could potentially be damaging to someone's reputation or is sensitive in some way or another. In post-publication, it becomes "forensic editing" to figure out how the situation reached its current state and to see what went wrong and what can be done to correct it, 
likely with a correction or sometimes with a Letter to the Editor. She said some journalists are not as well trained to deal with complaints and their instinct tells them to just make the change and correct the quote or just remove whatever the questionable text is. "But when you do that, it's almost an admission of guilt," she said. Editor 4 added that we tell them to just leave it, and training happens regularly since the newspaper has a great group of First Amendment lawyers to work with. While corrections and changes do get made, the important thing is to not just make rash changes without being "totally transparent with readers."

Editor 4 explained an example of a request that resulted in some alterations. Vanity Fair excerpted a book about the downfall of Merrill Lynch, and Editor 4's newspaper blog picked up the juiciest part about one training floor executive's tyrant behavior. Neither Vanity Fair nor the book had any comments directly from the executive. His lawyers called to complain that the text was not true, and despite picking up the content from elsewhere, Editor 4's newspaper still owned that blog content. She said, "Our defenses were only as good as Vanity Fair's defenses, which is only as good as the book publisher's defenses." The defenses were not strong, so the newspaper removed the allegations and put a correction explaining that the executive denied allegations and the newspaper should have contacted him directly. In this example, Editor 4 removed a significant portion of the article. She emphasized that it is important to figure out how the staff got to where they are in every case individually before taking action.

Editor 6 said they do not get a lot of requests, and it is "pretty infrequent." While it is common for someone to call in with a correction for something posted online, it is 
much more rare for anyone to ask to have content taken down, but "we are asked from time to time." Having been at the paper for more than a decade, she holds a higher level supervisory role with responsibilities in policy setting and dealing with tough situations, and she said she is generally in charge of dealing with all the requests. Editor 5 plays a similar role in that he is the "final arbitral" in the decision-making line and all requests pass through him or reach him eventually, and the request gets discussed between himself, the managing editor, and the Web manager.

The newspaper where Editor 3 works has an online director and approximately 30 to 40 stories on the home page at a time. He has been in journalism almost 40 years and only a handful of years at his current newspaper, but he is responsible for what is published and what is removed, but a lot of other editors handle posting onto their respective pages (e.g. sports posts to sports pages). The Web editor is responsible for handling the front page: changing stories around hourly, updating stories, adding and removing from the home page. He said, "The news desk and the city desk, business desk, so on, just moves the stuff as fast as they can." He could not recall ever removing a story but said complaints come in fairly often.

Editor 2 said requests came in once or twice a year, but some of them were "frivolous," such as an inmate claiming to be wrongly convicted and wanting the story taken down. But without a policy, the complaints are dealt with case by case. He said some cases are more complicated, such as a victim saying his or her life is being endangered by the story. Editor 2 has almost 40 years of experience, including 20 years at his current newspaper, and is in charge of content operations in both the print edition and 
online. Complaints will go to the original editor and then up the management line to a content director (the paper has two content directors for print and online), and it may reach him and may involve lawyer attention.

In the year and a half that Editor 1 has been at his current newspaper, he has seen three or four requests. He said, "Usually it's people who had something happen that we wrote about and they want the story taken down because it's ruining their reputation or whatever." He described one instance where someone complained that the charges in the arrest story were dropped, so they added that information into the original but did not remove it. He said, "If somebody did something and we wrote about it, the general rule is we don't take it down."

Editor 5 said he only gets six to nine requests a year. Similarly, Editor 8 said he did not get many requests for removal, "It was unusual to have someone call and say would you remove something from a story that's already been in the paper." But he did get complaints over stories being wrong or inaccurate. In those cases, the public editor would step in and advise a correction.

\section{Most common reason for requests}

The number of requests varied with most editors explaining that they do receive requests for removal but just do not generally do it. Most complaints revolved around embarrassment (or source remorse) and issues with criminal stories. English said some of the complaints are source remorse where someone is embarrassed by what they said. She said others relate to criminal charges such as when charges are dropped and the 
newspaper failed to continue reporting on the matter. Some are people convicted of crimes who just do not want it on the Internet. One of the cases sitting on her desk during the interview was a family that talked about financial troubles and now three years later they want the story taken down. Editor 6 reiterated that by saying most reasons are from people wanting something from their youth to go away or they were named early on in a crime story and have since been acquitted.

Another editor (Editor 2) also referred to crime and embarrassment. He said the most common is someone accused of a crime or involved in a crime who feels the story puts them in a bad light, or someone is embarrassed by how it turned out. He gave an example where a policeman was facing disciplinary action because it got out that he was having an affair and he wanted it taken down so his wife would not get upset. The newspaper refused. Legal reasons or persons complaining they are cast in a light they are uncomfortable with are reasons he hears, but the most common ones are to do with crime.

Editor 7 also said the most common reason was embarrassment such as when five years down the road people think differently about what they originally said. A few years ago technology was not as big as it is now and people are suddenly realizing that they can find stories about themselves on Google. He said, "Especially I'd say from 2005-2010 when the Internet was becoming bigger and bigger, I think some people were astonished about that and they think, hey remove this." But Editor 7 is firm on not removing anything and referred to the cliché, "You can't put the genie back in the bottle," and if it has already been published, it cannot be taken off the Web or out of print. He believed in being fair, accurate, and credible, but it is illogical to think that the newspaper will do a 
fluff piece to follow up on a person that did something stupid 10 years ago just to say he is doing great today.

Some complaints were about plain, old inaccuracy. Editor 1 said the reasons vary but often it is people who think the story is inaccurate or that they were portrayed wrong. He said, "I've had hundreds of these conversations with people over the years. There's never any one complaint. It's usually very specific to them and their issue." Usually people are not satisfied with being told the policy is to not remove a story and eventually he has to end the conversation politely. Editor 3 said that while it is hard to pinpoint the most common complaint, one fairly common one is someone saying he or she did not give permission for the story to be written. His response is to explain that the newspaper does not need his or her permission. He explained that the protocol is to get information from credible, reliable sources and to always contact everyone involved and get comments.

So it is apparent that complaints vary but they tend to revolve around source embarrassment and crime coverage. Editor 5 said the most common complaint is regarding sports pages and parents or someone calling to complain about how the newspaper missed a certain event or certain athlete. He said, "The thing about complaints is, as I've talked to our managing editor and some other editors, is you can never tell. You never know what's going to trigger something," and they do get complaints over tone and content (such as sexual content). Reasons for wanting stories taken down are not "high-minded" and usually involve embarrassment or concern over reputation (especially when it comes to stories on marriage and divorce). 


\section{Newspapers with policies}

Clearly requests and complaints are reaching the newsrooms in this study on a fairly regular basis, and though editors lean on the side of not removing any content, occasionally they do think about it and rarely, they do it. So this must mean that newsroom's have some kind of best practice or policy in place for dealing with such situations. But not every newsroom does. In fact, most of the publications in this study do not include unpublishing in any of their policies at all and if they do, they choose not to share the policy with the public. The Toronto Star is one of two newspapers in this study that has a firm policy in place and makes sure that it is easily available to the public. The Star's online "Policy and Journalistic Standards Guide" includes a variety of topics such as ethics and libel. Under the subhead "UNPUBLISHING" it states:

The Star sometimes receives requests to remove content from archives or websites, whether because they are erroneous or considered embarrassing to a member of the public. Generally, we do not unpublish content from our websites or archives, except in some rare circumstances following consultation with the editor and public editor and in some cases, legal counsel. In the case of verified errors, we will correct/update the article and/or append corrections as necessary.

English was surprised that other newspapers are not more open with their policy but said her 2009 report is outdated and it is possible that more newspapers have added policies. The New York Times and the Washington Post have public unpublishing 
policies but they are hard to find. English said The Star was going through a rewriting of all its policies and it was good timing to add unpublishing when she came on board. The policy was created in a meeting with the newspaper's lawyer and digital director. Some of the motivation behind creating the policy came from how surprised English was by how many requests were coming in. She started at The Star in 2007 and listening to removal requests was a new issue after many previous years working as a journalist.

The policy at Editor 1's newspaper is that if the story is accurate when it was posted, then it stays up, and if there is an error, a correction is added. Editor 1 said, "I don't believe that they would take something down. But again, I don't know. Maybe somebody will present a compelling case one day and that will happen, but it hasn't happen yet." However, the policy is not available to the public. Similarly, Editor 4's policy is to not remove stories, but that policy is kept internal within the newsroom and not publicized. Editor 8 has a strict policy that says the newspaper does not remove anything. Another editor at Editor 8's newspaper helped make the policy by discussing the issue and agreeing that stories cannot just be removed. His policy is one of two in this study that is readily accessible to the public (the other being The Star).

\section{Should newspapers have a policy?}

English said having a policy is tremendously helpful:

I think it's very helpful that readers know where you're coming from. For me as a public editor, it's very helpful because this isn't me being some mean person and not giving them what they want. This is the 
Toronto Star's policy, and it's based in ethics, it's based on [telling] our readers what happened.

While she was very clear why she believes in having a policy, the majority of editors did not agree with her and did not have a policy nor did they want to have a policy in the future. Editor 8 said it is important that the newspaper is the one to voluntarily decide whether or not to have a policy, and it should be made "clear and available" to the public, which he thinks his newspaper does. The policy at Editor 3's newspaper is straightforward but not public. The paper does not take stories down unless their corporate lawyer demands it. But, he said that for an article to be removed it would have to be a fabrication or huge mistake.

Editor 1's opinion is that if someone takes the time to call and if there is a compelling reason, editors have a responsibility to listen and consider the options. But, he said, "I don't think a blanket policy works," and added that he does not think a blanket policy works for anything. He said every case is so different and "needs to be judged and looked at on its own merit." He did not think that an industry-wide standard was "within the realm of possibility" because everyone cannot agree on every detail. Each case, he said, should be looked at on its own and decisions have to be based on each particular situation because there are small nuisances and in order to be fair and accurate you need freedom to consider everything without a blanket policy telling you what to do. Similarly, Editor 2 said his newspaper looked at unpublishing case by case, and it would be hard to have a policy because it is situational and hard to be really specific unlike with corrections policies that say if it is inaccurate, it will be fixed. He said it is important that 
people feel they are being treated fairly and added, "I don't think you want to have a policy that says you will do this or you won't do this," but instead newspapers should be careful and focus more on doing the right thing.

Another editor against having one policy was Editor 7. He said he was unsure how one would create an unpublishing policy that adequately applies to everything, but most papers have ethics policies for fairness, integrity, and corrections. He said maybe the policy should say something would be removed when it is libelous or "amazingly inaccurate.” There is a lot of gray area, and often cases of privacy or fairness might not instigate a lawsuit while libel could be compelling enough. He listed an example of a national security matter and when it came to publishing it, five editors would likely have five different outcomes on how to handle it. He said, "There's not a policy that's going to steer you toward 'Here's how we're doing it,' other than have a good thoughtful discussion about it."

The legal aspects of journalism came up with Editor 7 when he said, "If you thought something that you wrote was really unfair, or maybe not even libelous but just inaccurate and unfair, you might take it off the site," but his newspaper does not have a policy in place. He thought there would have to be a really great error or libelous content, and he would not remove something until a lawsuit called for it because taking it off too early would have the attorney asking questions and then having to argue over a mistake that has been admitted too soon. He said if his newspaper did not stand a chance at winning a lawsuit, he would take it down or rewrite it, but his first instinct would be to try to make the story fair before taking it off completely. He added that most newspapers 
have ethics policies that address at least the digital aspect of publishing and making errors, and newspapers should have policies or practices for handling errors. But, it is not so simple with unpublishing because "what's fair to an editor might not be fair to the person we are writing about." He said it is simplest to focus on fairness:

How do you be fair to the source and make sure you're accurate and credible so that you can stare at anybody in the eyes and say we're fair and we have our credibility? You want practices that sort of go that way.

One editor (Editor 5) was strongly against even using the word "policy." He said, “When you use the word 'policy' you imply that it is written, and we have not written anything." He prefers to carefully use the word "practice," and his newspaper does not have a policy, or practice, for what to take down. He said, "Our practice has been that it is the, that the accuracy of our archives is of paramount importance. Any request has to surmount that obstacle (which is rare)." If the newspaper was to make a policy, he said the next situation that came along would probably not be covered by the policy. The way they deal with requests is to discuss it among three staffers and usually run a correction. He said, "If we can, we'll try to help the person, but we're not going to take something down simply because they ask for it."

\section{Does a policy invite more trouble?}

Much like the opinions on having a policy, the discussion over whether or not a policy invites more problems also brought out varied results. English said she thinks it "definitely invites more complaints because everybody sees it" and she has seen more 
requests since The Star's policy was published. She said, "The easiest thing to do is to hide the policies," and policies have enough gray areas to be open to interpretation. According to English, part of her role as public editor is to interpret policies and she felt it is important to be transparent with readers so that they know where the newspaper is coming from (and The Star's policy helps to do that).

Contrastingly, Editor 1 disagreed with having a policy available to the public because "that would be like asking for it" since complainers suffer from "tunnel vision" and they do not listen but only focus on ways to attack. He said giving complainers a policy to latch onto would mean sitting around all day listening to calls from angry readers. He said, “If you're all the time babysitting readers who've felt they were wronged by something, you just can't do that. It's not feasible. There are not enough of us left to do that." His statement is a bit ironic since the industry is arguably growing smaller with less copy editors but more and more copy, especially online.

The policy at Editor 4's newspaper is well known to everyone working inside the newsroom but remains hidden from the public. She said it is the newsroom's philosophy to not "air how the sausage was made" externally and they focus on practicing "no surprises journalism." Practices are passed on by word of mouth, and they do not have a book of internally published policies. The newspaper does not have a public editor or an ombudsman but operates solely with the ethics and standards group (Editor 4 is a part of the group). She said that if an issue or problem came up, it is fastest to resolve it by talking within the group because they have complete and direct access to everything they need to get to the bottom of a problem. 
She said the lack of publicized policy is accepted because there is no ambiguity with the readers; everything that is changed or corrected is made obvious to the reader right when they arrive on the page. Editor 4 said she is not sure if having its policy publicized would invite more complaints but that is not the reason they do not have it on the website. It is not posted because of legal reasons, "We're human, everybody is going to make mistakes sometimes," and someone will say the policy says you will always do this and you did not do it, so it is negligent. Editor 6 also referred to legal reasons when she said that the newspaper would not have the policy available for the public (if it had one) since there are pros and cons legally to having policies written out. She said, “Sometimes it makes lawyers nervous if you've got a policy written down. It could be used against you in court, for instance."

One editor who did not agree with legal consequences was Editor 8. His opinion was that if you have a policy in place saying you are not going to change something, and the problem will only exist if you violate it, and so complaints and legal troubles will not necessarily increase. His argument was that having a policy would prevent the newspaper from violating it and thus limit problems. He referred to the newspaper's obituary policy that requires the cause of death. A prominent CEO's friend committed suicide, and the man did not want the cause of death in the obituary. But the newspaper refused to comply so his only option was to not have the obituary published at all. The CEO was upset, but the newspaper would only consider re-evaluating the policy after it refused to change it for him. Editor 8 said, "If you have a written policy, it's a stronger guideline for those who follow you." 
When asked if the policy was available to the public, Editor 8 said he thought the policies were on the webpage and if anyone asked for it, the newspaper was open about sharing it. He said, "We were pretty open about things. I don't really specifically recall if our policies or procedures would be available to the public. I just don't remember.”

\section{Solution 1: Not publishing names}

Some solutions came up during this study that could help either prevent or solve unpublishing problems. One of Editor 6's newspaper policies is to not publish the name of a person involved in a crime or an arrest until a court has officially made a charge. Doing so eliminates the chances of unfairly ruining someone's reputation online and allows for reporters to follow the important stories instead of every arrest.

Editor 6 said the most common complaint is from someone involved in the criminal justice system. She said, “They will say things to me like that was a long time ago, and I'm a better person now, or I'm trying to get a job, and this is getting in my way. Can you just take it down?" Her newspaper uses a proactive approach to crime stories and does not publish the name simply after an arrest nor does it run mug shots. The newspaper's standard policy is to "require at least one level of adjudication before that person is named" such as an arraignment or a charging. She said, "That's how we avoid so much of that [complaints for removal]." Editor 6 said it is important for a second reason in that it commits the newspaper to take up the responsibility of following the case to the very end. Sometimes the story does fall through the cracks, and the person involved in the arrest complains that the story reported they were charged but they were 
let go, so it is only fair to make an addition. She said in those cases they add a short story saying what happened so anyone searching for that person online can see both sides of the story.

Editor 6 said there is too high of a chance that someone is accused of something they did not do and they can suffer greatly from unfair news coverage. She said we lose a name in as story but it feels like the right thing to do. Recently, a suicide occurred in her city, and it was up to her newspaper to decide whether or not to publish the name. She chose not to use it while broadcast outlets chose to name him. While that is a different sort of scenario, it runs along the same line. English was open to the idea of not using names but said, "Our view is it's not our job to keep secrets, and if there are names [included] we should probably publish them." She pointed out that the problem really gets out of hand when newspapers aggregate copy every day.

Similarly, Editor 8 had a strong opposition to the websites he referred to as "extortion sites." He said these kinds of sites are publishing mug shots and even charging people to have their mug shots removed. Editor 4 also said it is "crazy" that publications make money from mug shot sections. Editor 8 said the best way to deal with these things is to not re-report but to make sure you publish a story on the outcome if you publish a story on the original charging. He said while it may be impossible to satisfy everyone, it is harder for someone to make a case for removal when thorough reporting has been done and everything is accessible online. In regards to withholding names until charges have been filed, Editor 8 said those two happen simultaneously in most cases and: 
[He] would be very nervous about that because, at the moment you say you're not going to do something like that you're giving law enforcement carte blanche to arrest people, to harass people and to release them before planting any charge, and you don't want a system like that.

\section{Solution 2: Group discussion}

A number of editors explained that editorial decisions to remove and make significant changes to stories were discussed within a group and rarely decided alone. Editor 7's best practices for dealing with requests involved having three to five people around to discuss it. He said it might include the editor, managing editor and the reporter, but it varies. He thinks every organization likely differs in how they handle these discussions. Editor 5 said that when unpublishing requests reach him, he discusses it with the managing editor and the Web manager. Editor 2 had a more simple explanation, he discusses it with "everybody who is appropriate," including the reporter, story editor and ethics editor. He said, "I'd bring a wide group of people into discussion because I don't want to make a decision in a vacuum. I want to hear from other people about it." English said it is important that not only one person makes the decisions of what stays and what goes but for the decision to result from a group discussion including the editor, lawyer and managing editor.

Other papers make sure the cases go through a number of different hands. Editor 2 said that there is a general system where requests go through content directors and then reach him before he discusses it with a number of people. Editor 8 explained that his 
paper's policy to not remove stories was made through a group discussion, and that is also the process of dealing with any significant unpublishing request that comes up. The discussion takes place between higher-ranking editors and they ask each other, "Do we, as a newspaper, want to remove this story?" He said, "You have a discussion with your best minds and make a decision." His newspaper does have a stylebook, and he is pretty sure it says to not change the public record. The stylebook is an effective way of getting the message around since it is circulated well within the newsroom and people read and discuss it, he said.

Editor 6 referred to the earlier example involving whether or not to name a person who had committed suicide. She said the way the newsroom does things is to have a group of people get together such as the reporter, online producer, and business editor. The conversation allows the journalists to consider pros and cons, and while Editor 6 makes the final decision, she does not feel as if she is making the decision alone:

I think that's how that has worked for us in safeguarding against either having people just go react in those situations without knowing they have to stop and ask somebody. I think a collective conversation generally leads us to a better response than any one of us doing it alone. That's just the way we do story selection. That's kind of the way this newsroom operates.

Handling tough requests with a group discussion is a common strategy across the group of editors. The consensus amongst all the editors was that the best practice for making 
complicated decisions is to gather together the most knowledgeable minds in the newsroom and talk it through.

\section{Solution 3: Putting up a note}

In the case of removing the kayaking photograph, Editor 4 said that the newspaper put up a note saying that they failed to make it obvious that the kayaking company and person in the photo had nothing to do with the incident in Chicago. She said, "When we remove content what we do is we always tell readers that we've removed the content and why. I say always, I mean nearly always." She said that repeating the error is "never a worry" since the error is already out there and it is more important to explain the magnitude of the error. English agreed with Editor 4 in that when something is removed she tries to best say the reason for it (such as a legal reason or it failed to follow a policy). Editor 6 also believed in putting up a note to be transparent with readers but was not sure how to do so without further outing the person, "We're pretty big on transparency with readers," she said. "I would be thinking about what we could do to be transparent for readers but that sounds difficult to me." When it comes to concerns over repeating the initial error in the note, English said there is "always a line to walk" when it comes to transparency and repeating an error but they try to give readers the whole story, if possible. Editor 3 said putting up a note would depend on how it could be done but believed they should acknowledge if they screwed up badly. Editor 5 said they did not put up a note and just took the story down in the case of the marriage story involving a person going to Afghanistan. 
There are pros and cons to this strategy, and it looks as if it depends greatly on the context of the initial error. Putting up a note increases transparency and reduces reader confusion but it also calls more attention to the initial error and increases the chance of doing more harm. It is really up to the newspaper to decide which method is more ethical, and it will likely vary greatly from case to case.

\section{Solution 4: Letters to the Editor}

Editor 4 was one of the editors more open to removing content and being transparent about the process with readers, despite having an internal policy to not unpublish. She said sometimes the situation could be remedied or improved by publishing a complainer's Letter to the Editor. As a part of an ethics and standards group, she first determines how the situation has reached its current point through "forensic editing" and then thinks of options, if a remedy is necessary. She said, "We don't correct errors in Letter to the Editor, but sometimes the fairest thing is to give the person who feels wronged to have another outlet to talk to directly." The newspaper is not required to publish the letter, but it could be useful to readers to have more information directly from the source, though in some cases the letter would just attract more unwanted attention. She said, "We'll use Letters to the Editor to be fair. We'll never use Letters to the Editor when we've done something wrong. When we've done something wrong, we fall on our swords with corrections and come clean on those." She stressed the importance of not alluding to errors but clearly putting it on A2 of the print newspaper and also including it in an obvious location online. 


\section{Power of the digital world}

When it comes to addressing how the newspaper world is adapting to the growing power of the Internet, Editor 1 said that everybody is still learning the online world, including journalists. Others reiterated that idea. Today's publishing emphasis is more on speed, and Editor 1 said this could compromise accuracy. He referred to the Boston marathon bombing as an example because, in a rush to be first, a New York newspaper put up a photo of the alleged suspects and turned out to be completely wrong. He said,

You have to be cognizant that in your quest for speed you may make some errors just because the information isn't available yet or you didn't have time to get it. And for that reason alone, I think you have a responsibility to make sure that the stuff that is online it's accurate, because when it's up there, it's up there pretty much forever.

With the trend of new tools popping up, such as Twitter and Facebook, Editor 1 said that journalists would have to adapt to the changing environment. He said the communication world is different now than it was but newspapers are "so uptight" and have stayed the same for hundreds of years.

According to Editor 1, the issue of unpublishing will likely come up more often since it was not a problem 10 years ago. He said, "Who knows, 8 years from now with something like this, what the issues are going to be? It could be anything. It's impossible to say, but you have to stay flexible to be able to deal with it." Editor 2 agreed that unpublishing complaints will increase "because everything lives forever" and it is not like 
in the past where printed pages were only savable if someone kept a clip. He said, "Now, in the digital era, things don't go away, don't disappear in the way that they used to. So that will make these kinds of situations more and more common." Editor 3 also agreed that unpublishing would continue to become a greater issue especially because of “amateurish" websites that aggregate news content. He said his newspaper's motto is not just to be first but also to be correct and then first. He reiterated the importance of having a credible, reliable source.

Editor 6 thought newspapers will get more requests because people are beginning to understand the Internet better and are more aware that their online legacy lives forever and employers are using Google searches before making hires. She said that online reporting standards are the same as print and the most dangerous platform for the future is social media, but they do a lot of training on proper social media use. Editor 4 added that when she began working as an editor, communication was through snail mail and phone calls but now more people can access content solely through the Internet and communicate instantly with emails, and so that is a reason they hear from people way more than they used to. So not only are people more aware of what is online, but they are finding it easier to communicate their complaints.

Editor 7 said that this day and age is about immediacy and there are going to be more and more unpublishing cases because there are more and more stories going online and not even making it into print. He referred to Twitter and Facebook and how it is easy to post something too soon and added that aggregation sites are furthering the problem. When one website publishes a story and a lot of others pick it up, it becomes even more 
challenging, and "this will become probably more of an issue and the bigger issue in the future than it is now just because there are so many more avenues of social media." Editor 5 was strongly against unpublishing and having a policy but agreed that as newspapers become more digitally oriented, requests will certainly increase. Editor 8 was also very against removing material from the web and agreed that requests would increase but focused mostly on websites that post mug shots.

All of the editors were in agreement that unpublishing requests would become more and more common despite the majority of editors not wanting an unpublishing policy and not being overly comfortable with removing stories. The fact is that the online world has changed journalism by increasing the amount of content published daily and publishing it on the Web first. There's also been an increase in instant communication, so not only are people more aware of what is being posted and what their online image is, but are capable of voicing disagreements more easily. This combination of Internetrelated factors makes it impossible for unpublishing to decrease.

\section{Reasons against unpublishing}

Despite the fact that unpublishing requests will likely increase, editors brought up a number of reasons for why they were strongly against unpublishing. Yet again, the Internet was a highly talked about topic and how the power of Google searches and the number of websites posting the same stories makes it nearly impossible to ever entirely remove an article. 


\section{Remains online forever}

Often editors raised the argument that whatever is published online will likely remain online forever despite efforts to remove it. One of the editors (Editor 7) discussed a case where a teacher wanted a story about an old firing to be removed, and he said that even if they did remove it, the story would still be on the Internet. Editor 2 said that they try to do the right thing and if the right thing is to take it down, they will do it but even if it is removed it is likely still cached somewhere else and might not disappear. He was personally involved in a case in which it was reported that he fired a family member. $\mathrm{He}$ said, “Any of us, too, who've had journalism done to us, as it were, know how these things can live on the Web forever." If his name is Googled, that story comes up. He said it was not true and complained but it is still out there and going to live a long time on the Web. He justified it simply with, "That's the way it works." The original site that reported the inaccurate story refused to change it, but other sites that picked it up did make the correction. No one removed it, but he admitted he did not fight it very hard.

Editor 6 said it is not possible to ever completely remove something from the Web in the "world of Google and cached websites," and Editor 7 had a similar reasoning and added that the removal would have "limited impact." While it is very true that stories get passed around different websites easily, it still sends a message when the original publisher removes the story. Removing it shows that it was wrong, and pushes other sites to act as well or else risk being inaccurate and not credible. It is a myth that website managers need permission to remove a story from Google. Removing URLs from Google is a simple process that anyone with Webmaster access can do. 


\section{Removal compromises future need for information}

While a few editors were in agreement about not publishing names of arrests until a charge had been filed, Editor 8 said it would be risky to keep the name out of early

arrest reports because, "You're rendering, for all practical purposes, invisible a huge part of the criminal justice system." He added, "Every prosecutor is going to look like he or she has a 100 percent conviction record. You're not going to get any sense of the overall priority or scope of the criminal justice, or for that matter the civil justice system." He also said that he thinks it is dangerous to remove this sort of information even if the argument is compelling or enticing because "sooner or later it's going to come back and haunt you [if you remove].

He gave a real example to explain how something in the distant past can be very relevant today. In a race for state attorney general, the topic of whether there should be a crackdown on drunk driving came up. One candidate who had been against increasing punishments was discovered to have a drunk driving incident on his record from his teenage years. Soon after, another candidate came forth admitting he too had a drunkdriving incident from his distant past. Editor 8 said, "Do we want to do things to make it more difficult for those kinds of pieces of information to come out?" He suggested that no one would want to make information less accessible to the public and to journalists since it is impossible to forecast what someone might do in the future and if that information will become relevant. 


\section{Preserve the archive/ public record}

Newspapers are a historical account of the day's events. Journalists take careful measures to produce accurate, truthful accounts to add to that public archive. Editor 9 said that he refers to journalism as the first draft of history and altering stories would be asking for trouble:

I can't imagine a situation where if you're publishing something and you're basically trying to create a record of what happened that day, and that's where I think it goes off track. If you get it wrong, you can correct it and all these other things. But to remove it, you're saying that on such and such day, this happened, but we're not going to record it. We're going to remove it from that record. From a policy perspective, you're just asking for trouble.

Editor 2 had a similar sentiment in that a lot of things happen every day and it is recorded in history so it is not going away, and there may be no reason to remove it. Contrastingly, English said she understands that with the archive there has to be integrity with what is published but just saying journalists are tracking history is not a case for not removing a story.

\section{Newsroom legal awareness}

The presence of the law was impossible to avoid when it came to discussing unpublishing. While the law could easily be a direct reason for unpublishing if a court

ordered the removal of content, none of the editors had ever had to deal with such a case. 
Every newspaper editor interviewed had particular lawyers and legal counsel they consistently went to for assistance and guidance. When it comes to legal consequences, it is hard to tell exactly how prepared a newsroom staff is but a number of them take part in training and staff meetings to maintain a decent level of education on the matter. Editor 1 believed the staff is very aware. The newsroom recently attended a legal seminar with the paper's legal team to talk about laws and online journalism. He added that the staff is made up of actual human beings who care about what they write. Editor 2 felt similarly about his staff's awareness. He said they do regular sessions on privacy and the digital age as well as libel:

Our staff is pretty up to speed on those things, and, of course, we have editors to backcheck them. I have a lot of confidence in our staff's ability to know when to alert somebody that something may present a legal issue of one sort or another... And I think we have outstanding legal counsel for when we need it. There's no such thing as perfect but I think we're in pretty good set on [knowing what to do].

English said her staff is "absolutely" aware and the newsroom does regular training on law, fairness, etc. Editor 3 was also confident in his staff since most of them have been part of a journalism program and have received good training. He said editors are well aware of the law and if there is a red flag, the newspaper's lawyers take a look at the article before it is posted. His newspaper had not been sued in the three years he has worked there. He said, "We are cautious, but we are not timid about putting stuff up." Editor 6 said the newsroom discusses law often: 
The mantra in the newsroom is if there is ever a question about anything that could become a legal matter, just raise the issue. Giving us a chance to have a conversation about it and decide if there are any legal implications.

She said that the staff knows to stop talking when someone threatens legal action and to refer him or her to the newspaper's attorney.

Other editors were less concerned. Editor 5 simply said he does not know how each staff member feels but he does know they know the policy is to not remove a story. Editor 4 said she does not want reporters to worry so much about the law but editors know it is their responsibility to know if something could trigger a lawsuit. It is her responsibility to decide whether lawyers need to be brought in. Editor 7 thought some staff members were more aware of legal consequences than others but said the newsroom discusses issues such as libel and fairness a lot. He said every couple of years something will come up such as Jayson Blair at the New York Times and that will trigger discussion that increases awareness even more:

I would say that in most newsrooms there is pretty good awareness about issues of libel, issues of fairness. Again, you have to talk about it because of people's sliding scales about what is fair to write about a person or an issue. There's a lot of gray area.

Overall, the editors were confident in their staff's knowledge of the law and how journalism has a close relationship with the law. The fact that every single newsroom had a lawyer on hand shows that there is a relationship between journalism and law, one that 
is bound to butt heads occasionally. When it came to facing actual lawsuits, all of the editors said they had never been sued over an unpublishing case but most have faced lawsuits at some point in their careers.

\section{Lawsuits}

Newspapers get threatened with lawsuits on a regular basis, according to most of the editors interviewed. For example, Editor 6 said they get sued all the time but most of it is when the newspaper wants documents and someone will not provide it. But there never has been a lawsuit about unpublishing in the newspapers studied here.

Editor 4 said, "We get threatened all the time," but the only lawsuit that made the newspaper take something down was in Germany. She said, "We live by the rules in the jurisdiction where we work, where we have assets, where have people who could be in some cases found criminally liable for things." When reporters worked on the Libor story in the United Kingdom, the courts demanded they remove it from the Web, and they did until they ended up winning a reversal. But nothing of the sort has ever come up in the United States.

Similarly, Editor 2 said:

I don't think anybody who's been in our business for a long time has not had to deal with a lawsuit or threats of lawsuits and retraction demands and so on and so forth. And again, if it's wrong and it's 
significant, you retract it. If it's right then you stand by it, and if somebody decides to sue you, you deal with the consequences.

He said the newspaper has been pretty successful at winning cases. When asked if he would remove an article if a case really did call for removal, Editor 2 said absolutely and referred to the law as the main reason. He said, "It's not inconceivable as a condition of a settlement of a lawsuit could include removing the story from the web. Obviously, if it was terms of a settlement, we would abide by the terms of the settlement." While it has never happened to him, he does not rule out the possibility of it happening. So a lawsuit about unpublishing is possible.

The only time Editor 3 directly dealt with a lawsuit was when he was involved in one himself about a public agency's unwillingness to give what he argued was public information. Editor 5 has also never had to deal with a lawsuit getting successfully filed and has never seriously considered an unpublishing case with a lawyer. The one time a lawyer had to step in was about an Associated Press story. A lawyer in Washington, D.C., demanded the removal of an article and asked that his client be paid $\$ 75,000$ in damages. Editor 5 said we looked at the story closely and it did not originate in their state and did not have any names (so the client was not even identified). An argument ensued between lawyers but nothing panned out, and definitely no payments were made so he does not consider that case to be of much importance. 


\section{Influence of complaints}

It is clear by now that newspapers get complaints and requests for content removal on a fairly regular basis. Despite the variations in number of complaints and readership size, it is possible that a fear of legal repercussions and/or fear of reader backlash could influence the reporting and editing process and consequently affect the published result.

A couple of the editors felt strongly that reporting remains unaffected. Editor 3 said, “Am I more cautious? No. There are chronic complainers, as you say, and they don't get any more consideration than anybody else." Editor 2 said no because he felt that the newspaper stays true to its values and treats people fairly, accurately, and appropriately. Editor 4 also said no, and rationalized that the newsroom workers have the luxury of being at a newspaper that is "well lawyered up and edited up." She listed an example of a reporter working on a spinal implant device story focused on spinal surgeries with certain physicians that hold stakes in the spinal implant companies. Stories like that take months, but she said that reporter will work closely with the standards and ethics group so instead of holding back on reporting, the reporter is taking care to do “bulletproof” work. A preventative practice and a way to ensure even more secure reporting is to have the reporter provide the questions via email or mail before the interview to make sure the source knows what will be discussed and understands everything completely. Doing so helps ensure that the reporting tone remains neutral and the reporter is not jumping to conclusions, Editor 4 said. She added, "We take a lot of care. I think now we're not afraid of people who are threatening us." 
Some editors were more open to the idea that reporters are affected by the threat of backlash. Editor 8 said it is difficult to tell but "it's hard to think that a plausible threat to sue might have no impact whatsoever." He said with the practice of sound journalism it is unlikely that these cases would come up but if there is "sloppy" journalism - and if it becomes easier for people to file lawsuits persuading newspapers to remove content then it would "give you pause in terms of what you're publishing in the first place [and] it would also raise a very serious First Amendment question.” Another editor on the fence, Editor 7, said "maybe," but if a reporter is aware they are writing about a difficult person, "it still comes down to fairness." He said it is natural to "bend over backwards" so there are as few errors as possible and the reporter may avoid "loaded words," which he noted should not be used anyways. He said, "A lot of times it is the little words that make stories come off as unfair." In particular, he referred to the use of the word "but" after a paragraph that could insinuate the reporter does not believe the source's previous statements. He said, “It's human nature when somebody's being a tough source. You may work harder to be as fair as you can."

Editor 6 said the newsroom is more careful in potentially sensitive cases and issues come up more with investigative work than anything else. She said, "I think you'd be silly not to be particularly careful with some people, more than others." But added that sometimes it is the people you are least aware of that end up being the most difficult, and so journalists have to be aware at all times. The word "careful" came up with Editor 9 as well. He said, "Obviously if a person is really litigious, you're going to be extraordinarily careful." He explained an example in which his newspaper was sued for libel and 
defamation over a story on prosecutorial misconduct. The newspaper spent a lot of money to defend and won the case, but still covered the story just like they would cover any lawsuit. He said, "You really sit down and say you can’t get anything wrong here ... You try to approach it with the same care as you would any story." He said it is likely going to be in the reporter's head that this story is different than others, yet he or she still takes the same care and concern for accuracy. He added that mistakes happen and things go wrong, but "all you can do is if you make a mistake, admit it, correct it and move on."

Being right was the emphasis of Editor 3 when he said, "More than we want to be sensitive, we want to be correct." He said he might be more demanding and have the reporter ask more questions if the story is capable of being potentially libelous. Overall, the editors were mixed over whether or not reporters and editors are affected by the potential of legal trouble or reader/source backlash. Enforcing extra careful reporting and putting more emphasis on accuracy and fairness were mentioned in most of the answers from editors. Despite some editors being hesitant to admit to being affected, being extra careful or taking precautionary measures counts as a sign of influence.

\section{Hesitancy to remove}

Despite all of the editors being opposed to the practice of unpublishing in the majority of cases, most did say they would remove a story if the situation truly called for it. Editor 3 said he relied on the newspaper's checks and balances to prevent any such case from happening but admitted he could imagine a staff reporter doing something irresponsible. Editor 1 said, "I'm sure that you can screw something up so badly you 
would have to take a story down," but insisted that most cases just need corrections. He said he has never witnessed an article's removal at the newspaper but that does not mean it has not happened at another newspaper. Editor 9 was vehemently against removing a story at any point. He argued that if you do it once, then someone down the road will say you did it for this guy so now you have to do it for me. He said that if something was done wrong, you can always apologize but then you are just drawing attention to the matter and "you'd be better off to just let it go."

Law came up when Editor 4 said she would remove "only if the legal risk was super high or if we've been ordered by the court to [remove a story]." But she said legal risk is never high enough. English said that she would remove if merited but there have never been any legal requests to take something down. She said that it would likely happen in the future from a judge's decision. If a lawsuit demanded the removal of a story, Editor 9 said he would say no. Refusing would technically be contempt of court. The newspaper can be asked to make a correction or to pay monetary damages but he does not believe it would have to remove an article:

Let's say we were wrong. We published an erroneous report on Thursday, February whatever it is, and that happened. You can't change that. It happened. So you can't ignore it, you can’t wish it away. You just have to say OK it happened. 


\section{RESULTS}

The first research question asks: How do or how might American newspaper editors respond to and deal with unpublishing dilemmas? A lot of answers about how to deal with scenarios revolve around journalism standards. Editors provide justifications for how they respond to real and hypothetical unpublishing cases. Some answers led to preventive measures (ways to prevent the requests from ever happening) and some led to solutions for how to deal with removing a story or placating a complainer.

\section{Standards}

Topics such as accuracy, fairness, respecting readers and sources, and preserving the archive come up regularly across all of the interviews. Those words fall within the category of journalism standards and focus on journalists' ability to maintain transparency, fairness, credibility, and accuracy (among other things). Most of the editors say they would add corrections or follow-up stories (especially in response to Scenario 1), and they emphasize the importance of maintaining accuracy at all times.

Editors say that curse or sexual words and anything that is offensive for no good reason would not make it to publishing. When asked if he would consider taking the name out of Scenario 2 or changing it, Editor 3 said his newspaper does not use pseudonyms. Using real names is also a standards issue since names improve transparency and make the source more credible. Changing names after publishing is not 
an easily accepted solution since it negatively impacts the credibility of the source and therefore could damage the newspaper's relationship with readers.

\section{Justifications}

Explanations and excuses for not removing an article come up in both the discussion of scenarios and in the other parts of the interviews. One common justification is when editors say they would never have published a story in the first place (especially in regards to Scenario 3 as well as in publishing the kidnapping victim's name in Scenario 2). Despite the obvious fact that the scenarios are hypothetical, editors hesitate to jump right into it exactly as it is described and insist on preventative solutions (such as not including the name) instead of accepting that the name was initially published. Another common justification is placing blame elsewhere. Some editors blame the teenagers' parents in Scenario 3 or on the police department in Scenario 2. Editors say that the negligence in Scenario 2 would not be the newspaper's fault but the fault of the police department that initially released the victim's name. The Florida Star v. B.J.F. case support this argument since it reversed a ruling against a newspaper and had only the police department pay for damages (491 U.S. 524, 1989). There are multiple systems operating in society, and the newspaper is not the sole provider of information nor is it solely responsible for causing problems such as negligence. But the newspaper plays a large enough role and can cause enough damage to be part of a lawsuit such as in the Florida Star case. Furthermore, parents give consent without their children's approval or police departments include names of victims, by accident or not, and this in turn influences what is published and what is not, and affects who is blamed for the damage. 


\section{Prevention and solutions}

The majority of editors refer to group discussions when explaining how and why they make tough decisions. The concept is that an environment with a group of knowledgeable journalists helps breed an open debate and eventually can produce the best possible solution. Some of the editors are strongly opposed to making decisions entirely on their own and even more against letting reporters or lower level editors just remove things as they see fit without discussion (especially in moments of panic or guilt).

Putting up a note or allowing for a complainer to submit Letters to the Editor are other solutions that came up in this study. The note allows for readers to understand why a particular URL looks different than it did before, and it reinforces total transparency. But the note also risks repeating the error and calling more attention to it, and that is why some editors said they would not put up a note. Letters to the Editor is another suggestion that arose, and that method allows the complainers to have the opportunity to get the story out in their own way. It might resolve the problem, but it can also run the risk of calling more unwanted attention to the issue.

Another preventative strategy is to not publish the names of arrested persons until they have been officially charged inside of the court system. Doing so lowers the number of complaints and request for removals (in at least one of the newspaper's studied) since it prevents the publishing of unnecessary arrests and guarantees that reporters will follow up on the right stories by eliminating the unnecessary ones. But not all editors are in agreement over this strategy mainly because it can damage transparency since not using 
real or full names lessens the credibility of coverage. Also, as one editor argues, it could allow for the police department to arrest people more freely since there would be fewer consequences from the public.

Research question 2 asks: What factors, especially regarding pressure from possible legal action, influence decisions to publish or unpublish? The law comes up frequently as both a reason to not unpublish and a reason to unpublish. Across the board, editors are aware of the law as both a friend and a foe, and it influences decisions on a regular basis. But most of all, editors cite a reluctance to alter the public record as the main reason for not wanting to remove articles, and also argue that once something is online it never completely disappears.

Legal concerns and the threat of lawsuits are common topics in all of the interviews (not only because they were included in the list of questions). A number of editors, including English, say they would remove a story if a court ordered the newspaper to do so. It would be natural to then assume that lawsuits and threats of legal action are influencing reporters and editors when they are working on sensitive topics, but not all editors agree on this. Some say that journalism carries on the same as always though perhaps with extra care and special attention to detail. But paying extra attention to a story because it might instigate complaints and lawsuits is still influenced reporting (and editing). Gatekeeping is the process of dictating what goes through a gate to reach the audience and what does not. So in editing a sensitive story, gatekeepers (editors) may leave some words or quotes out in order to be extra careful and accurate to better guarantee a lower chance of backlash. 
Another factor influencing unpublishing is the strong reluctance to alter the archive. Editors feel a strong obligation to maintain the public record exactly as it occurs and are not comfortable with making any changes other than additions and corrections. Journalism is a historical archive of day-to-day events. Once an article is written and posted, it becomes part of the archive, and editors are in agreement that changing the historical record rewrites history and doing so is wrong (in the vast majority of cases). For example, regarding Scenario 1, Editor 2 points out that since the wrongful arrest has already happened, it is on the historical record, and, since it is not going to disappear from history, there is no reason to take it down. So in many ways, the editors' desire to uphold journalistic standards is a factor that influences decisions regarding unpublishing.

The reasoning that even if a story is removed it will remain online forever comes up repeatedly in this study. It is possible for other websites to have the same story on their websites and those would remain online indefinitely. But taking down the story from the original website still sends an important message because if other news sites are sourcing the original publisher, and then the publisher retracts, it helps spread news of the removal across to other websites and news organizations. Just assuming the Internet will never allow for the article to fully disappear is not reason enough to not remove an article because it is not entirely true. Webmasters have control of what appears on Google, and editors are normally the Webmasters. The influence of the Internet on editorial decisions or lack of decisions in this case is obvious since it is hard to fully understand how it all operates (The fact that some editors think they do not have the power to control what appears on Google supports that.) 


\section{Theory}

The overall reluctance to unpublish and the lack of desire to have a policy acknowledging the existence of unpublishing is explained by a number of factors: a reluctance to alter the historical record, a fear of removing information that could become important in the future, the idea that the Internet does not allow complete removal, and the lack of legitimate arguments from complainers that are greater than just source remorse. Shoemaker and Vos (2009) explain that there are different levels of gatekeeping analysis, and in the case of unpublishing, it is apparent that individual, organizational, and social institution are the most influential.

At the individual level, an editor is influenced by his or her own journalistic duties within the newsroom and within the industry, and this helps him or her decide whether to pass or hold information back. The editors in this study have a lot of power in regard to what gets online, and their individual decisions carry a lot of weight. They are faced with making decisions regularly, and Cassidy (2006) explains how personal and professional background along with beliefs and values can be what drives the individual level. The editors are all of varied backgrounds, and their past experiences impact how they look at unpublishing, especially when they are hesitant to alter the archive. That respect for the archive becomes a core part of their practice early on. Editors follow a media routine from teaching reporters and to monitoring what is posted online and how people react to it. The individual habits are practiced over and over again, and editors are confident in their ability to produce accurate work. The individual level also includes the moral aspect, and a lot of editors refer to wanting to be ethical and fair. In trying to be 
moral, some editors were reluctant to go to extremes to remove a story for one person when another person may not end up with the same result. They stressed fairness, and in most cases, suggested corrections and follow-up stories. Voakes (1999) said that if journalists ignore legal and ethical reasoning, then it ruins credibility, so it makes sense that the editors are focused on balancing both legalities and ethics.

Extramedia forces are those that come from outside of the individual media organization. Law is an extramedia force, and it comes up repeatedly in this study, and it is definitely an influential factor in driving what information does not get published. There are so many laws related to journalism that every single newsroom in this study has a lawyer on hand and has at least some knowledge of laws as they relate to journalism. The organization level is relevant because the newsroom and the journalism industry have standards and policies that all of the editors refer to and feel obligated to follow very strictly. Enli (2007) said choices are not made in a vacuum and are affected by factors including editorial routines, journalistic culture, and market needs. Editors stress the importance of making decisions in groups, and this exemplifies the organizational level because a number of opinions and knowledgeable minds are weighing in on one editor's ultimate decision. While there is always room for improvement and changes to stylebooks, it is harder to change something as significant as never altering the archive. Voakes (1999) said that there are combinations of influences that affect gatekeepers' decisions, and it is apparent that a combination of the three (individual, organization, and social level) influences decision-making within the newsroom. 


\section{CONCLUSION}

The purpose of this study was to find out how newspaper editors deal with unpublishing requests, either real or hypothetical, and to discover what factors influence these decisions. The researcher interviewed 10 editors and through qualitative analysis, was able to come up with various categories to form results and answer the two research questions. The journalism industry lacks a full grasp on unpublishing's pros and cons and lacks an unpublishing policy. While some newspapers (such as The Star) have a policy in place, the majority does not, and, in the rare occasion that they do, it is not posted online for public access.

\section{Discussion}

While editors are quick to offer preventative strategies and ways to handle removal requests, the vast majority of editors does not have a policy in place and does not want one. Editors hesitate to have a public policy because they do not want to invite more complaints and stir up legal complications, and they often choose to not acknowledge the option of removal because the newspaper is initially against doing it. Editors repeatedly refer to "case by case" as a way of dealing with removal requests, and while all are hesitant to remove, the majority of editors say they would do so if the situation really called for it. The study discovers that article removal has happened by exploring a number of real cases and that editors express reluctance to remove articles even while 
admitting they would do it if necessary. Most of all, this study shows that The Star successfully functions with an unpublishing policy.

Bezanson's (1986) Iowa Libel Research Project said that plaintiffs contact the media first before reaching out to lawyers, and the media tends to respond in an offensive, indifferent, arrogant and/or insensitive manner. Despite the fact that the Bezanson (1986) study found plaintiff success rates were just 10 percent, the majority of plaintiffs that lost cases still felt that the lawsuit accomplished something. This study focuses on the media rather than possible plaintiffs, but similarly supports the concept that the media tends to respond in a dismissive manner (by not being flexible and by not acknowledging the possibility of unpublishing with their public audience). The editors in this study are strongly against budging from their routines, and even in the face of a lawsuit, some are still vehemently opposed to changing.

Another parallel with Bezanson (1986) is the fact that plaintiffs felt accomplished simply by instigating and (almost always) losing a lawsuit. It is possible that people who complain just want to get a chance to make a point or have their voice heard (seen in the way that Letters to the Editor appease some complaints). While editors are mostly against taking any action other than corrections or additions, the source of the complaint was almost always placated, and editors rarely deal with the same complaint over and over again. But the editors still receive complaints on a regular basis, and this supports the idea that unpublishing should be acknowledged and dealt with through a policy. 


\section{Limitations}

The limitations of this study include a number of factors. The sample size is limited to 10 , mostly because that number provides a glimpse of how editors handle certain scenarios and decision-making in regards to unpublishing. The small number means the study's results are limited since it cannot apply to all of America's newspapers. The researcher has interviewed editors on this topic before in spring 2013 and used hypothetical scenarios in this study to broaden the possibility of finding rich material instead of solely hunting for unpublishing examples (that do not always exist) (Pantic, 2013). In 2013, the interviews were with a small number of editors in Missouri and around the nation, and the previous study was used to help create the scenarios that could result in unpublishing or severe alteration. The researcher avoids any biases developed from that study.

The study's results are beneficial to both journalists and members of the public audience. The industry lacks a standardized unpublishing policy, and it is a gaping hole that has room for development and further research. The researcher is not convinced that not having a protocol for unpublishing is a solution because cases come up on a regular basis, and, therefore, there should be an acknowledgment that the possibility of unpublishing exists. It is possible that the results of this study will help editors better handle unpublishing cases and help them avoid future legal consequences, though it does not end the unpublishing debate since there are so many uncontrollable variables.

There is room for future study since unpublishing will only continue to grow into a larger issue as people become more and more aware of their online reputation. As the Internet continues to expand, future studies could study the effects of that growth on 
unpublishing requests. It would also be possible to study a larger number of newspapers and compare America with another country or even just compare regions within America to see how each area handles unpublishing. A further study could be more targeted by studying only certain newspapers with a certain circulation range, or only editors who have actually unpublished an article. Since this research involved only 10 editors, other studies could do well to incorporate a larger number of editors and include publications such as magazines. Magazines would be an interesting study because they often include a lot of personal feature stories and address more types of stories with greater freedom, as well as have a more targeted audience. It could become possible to study how many newspapers in the coming years create a policy and see how they decide to include it with their ethics and standards policies online.

\section{A recommendation}

The repercussions of having a policy would vary from newspaper to newspaper but simply having a policy stating that the newspaper does not remove online articles except in extreme circumstances would both allow the newspaper to make its intentions clear and allow readers to take comfort in knowing that the discussion for removal could occur if a case truly called for it. In doing so, the newspaper maintains a transparent public policy and strengthens the newspaper's relationship with its readers by being firm as well as open-minded and flexible. It is hypocritical to want to be transparent with readers on all topics except for unpublishing, and it actually draws more suspicion and question into the topic of unpublishing instead of just laying it out for the public to see and understand. Using The Star's policy as a starting point, a policy could read: 
We receive request occasionally to remove online content and as a general rule, we do not unpublish content, except in extraordinarily rare cases following discussion with the editor and legal counsel (if it is merited). We do regularly make corrections and updates in the case of errors or inaccuracies.

Unpublishing has happened and still happens, and for that reason this study is relevant. With the Internet only growing more dominant, it is impossible to ignore this issue. Instead of laying blame on others and relying on 100 percent accuracy with zero room for mistakes, newspapers should take the initiative to strengthen the standards they so proudly refer to. While it may seem impossible to create one standard policy for the industry to follow, it is also illogical to ignore the issue and pretend it does not exist. Editors have a lot of power when it comes to decision-making, and despite all of the pressures from journalism's standards and newsroom traditions, it is possible to be even more credible and transparent with a publicized unpublished policy. 


\section{REFERENCES}

Bezanson, R.P. (1986). The Libel Suit in Retrospect: What Plaintiff's Want and What Plaintiffs Get. 74 Cal. L. Rev. 789

Bezanson, R.P., Cranberg, G. \& Soloski, J. (1988). Libel Law and the Press: Myth and Reality. The Library Quarterly: Information, Community, Policy. University of Chicago Press: Chicago.

Bernard, H.R. (1994). Research Methods in Anthropology. Qualitative and Quantative Approaches. Fourth Edition. AltaMira Press: New York, NY.

Cassidy, W. 2006. Gatekeeping Similar for Online, Print Journalists. Newspaper Research Journal. Vol. 27, No. 2.

Chamberlin, B. F., Lee, W.E., \& Middleton, K.R. (2004). The Law of Public Communication. Sixth edition. Pearson Education Inc.: New York, NY.

Commonwealth v. Blanding, 20 Mass. 304, 3 Pick. 304, 1825

Crone, T. (2002). Law and the Media. Fourth edition. Focal Press: Woburn, MA.

“Defamation.” The Law Dictionary. Free Online Legal Dictionary $2^{\text {nd }}$ Ed. Web. 24 Oct. 2013. http://thelawdictionary.org/defamation/

Digital Media Law Project. 2013. "Proving Fault: Actual Malice and Negligence.” Berkman Center for Internet \& Society. Web. Retrieved from:

http://www.dmlp.org/legal-guide/proving-fault-actual-malice-and-negligence

Edmonson, Aimee (2011). In Sullivan's Shadow. Journalism History. Vol. 37, Issue 1, p. 27-38

English, Kathy. (2009) The Longtail of News: To Unpublish or not to Unpublish. Toronto Star.

Enli, G. (2007). Gate-keeping in the new media age. Javnost - The Public. Vol. 14, No. 2.

FCC v. CBS Corp. (2012). 132 S. Ct. 2677

The Florida Star v. B.J.F. (491 U.S. 524, 1989) 
Fisher, R. L. (2005). The Media's Indecency Dilemma: Can Public Outrage, Congressional Hearings, and Larger FCC Fines Stem the Tide of "Indecency" Flooding the Airwaves? USA Today, Vol. 133, No. 2716.

Gajda, Amy. (2012). The Justices and News Judgment: The Supreme Court as News Editor. Brigham Young University Law Review.

Gandia v. Pettingill, 222 US 452, 32 S. Ct. 127, 56 L. Ed. 267, 1912

Gersh, D. (1991). Heightened Sensitivity: SPJ Survey Shows News Media Are Getting More Sensitive to the Privacy Concerns of Their Audiences. Editor \& Publisher Vol. 124 No. 6

Gibeaut, John. (1998). Professional finger-pointing. Vol. 84, Issue 4. P.89

Given, L.M. (2008). The SAGE Encyclopedia of Qualitative Research Methods. Sage Publications, Inc.: New York, NY.

Gorden, R. (1992). Basic Interviewing Skills. Itasca, IL: F.E. Peacock.

Hall, S. (1975). Paper voices: the popular press and social change. London: Chatto \& Windus.

Harder, Amy. (2008). When defamation goes online. News Media \& the Law. Vol. 32, Issue 2. Pp. 37-39.

Hodak, G. (2012). March 9, 1964: New York Times Co. v. Sullivan Decided. ABA Journal

Holden v. Minnesota, 137 US 483, 11 S. Ct. 143, 34 L. Ed. 734, 1890

Hyde v. City of Columbia, 637 SW 2d 251 - Mo: Court of Appeals, Western Dist. 1982 .

Kenyon, Andrew T. \& Marjoribanks, Tim. (2008) “The Future of 'Responsible Journalism': Defamation law, public debate and news production. Volume 2, Issue 3

Johnson, J.C. \& Weller, S.C. (2001). “Elicitation Techniques for Interviewing.” Handbook of Interview Research: Context and Method. Sage Publications, Inc: Thousand Oaks, CA.

Kovach, Bill, \& Tom Rosenstiel. (2006). The Elements of Journalism. London: Atlantic, 2003. Print.

Lincoln, Y. S., \& Guba, E. G. (1985). Naturalistic inquiry. Sage: Newbury Park, CA

Lewis, Anthony. (1991). Make No Law: The Sullivan Case and the First Amendment. New York: Radom House.

Near v. Minnesota, 283 U.S. 697, 703, 1931 
"Negligence" The Law Dictionary. Free Online Legal Dictionary $2^{\text {nd }}$ Ed. Web. 24 Oct. 2013. http://thelawdictionary.org/negligence/\#ixzz2kwqKbDfs

New York Times Co. v. Sullivan, 376 U.S. S. Ct. 254 (1964)

Pantic, N. (2013). Should the Columbia Missourian have an Unpublishing Policy? University of Missouri School of Journalism.

Patterson v. Colorado, 205 US 454, 27 S. Ct. 556, 51 L. Ed. 879, 1907

Peavy v. WFAA-TV, Inc., 221 F. 3d 158 (2000)

Prosser, W.L., (1960). Privacy. 48 California Law Review. 383, 388-89

Sanders, Amy K. \& Olsen, Natalie C. Re-defining defamation: Psychological sense of community in the age of the Internet. Communication Law \& Policy. Vol. 17, Issue 4. Pp. 355-384.

Shoemaker, P.J. \& Vos, T. (2009) Gatekeeping Theory. Routledge: New York, NY.

Snyder v. Phelps, 131 U.S. Supreme Court 1207 (2011)

"Society of Professional Journalists Code of Ethics." (1996). Society of Professional Journalists. Retrieved from http://www.spj.org/ethicscode.asp

Richie, J. \& Lewis, J. (2003). Qualitative Research Practice: A Guide for Social Science Students and Researchers. Sage: London.

Roberts, C. (2005). Gatekeeping theory: An evolution. Communication Theory and Methodology Division Association for Education in Journalism and Mass Communication. San Antonio, Texas.

"United States" Freedom of the Press 2012. Freedom House. Retrieved from http://www.freedomhouse.org/report/freedom-press/2012/united-states.

Van Dijk, T. (1991). The interdisciplinary study of news as discourse. In Jensen, K.B. and Jankowski, N.W. (Ed.) A handbook of qualitative methodologies for mass communication research. (pp. 108-120). London. Routledge.

Voakes, P. S. (1999). "What were you thinking? A survey of journalists who were sued for invasion of privacy." Journalism and Mass Communication Quarterly.

White v. Nicholls 44 US 266, 11 L. Ed. 591, 1845 
Youm, Kyu Ho. (2012). Actual Malice in U.S. Defamation Law: The Minority of One Doctrine in the World? Journal of International Entertainment \& Media Law. Vol. 4 Issue 1, p130. 30p.

Zelermyer, W. (1959). Invasion of Privacy. Syracuse University Press: USA 


\section{APPENDIX A: Recruitment e-mail}

I am writing to invite you to participate in an interview for a master's thesis for the University of Missouri School of Journalism concerning how newspaper editors deal with the unpublishing of online content and the pressures of legal implications when publishing articles. The interview is for research purposes to study how decisions are made in newsrooms. Even if you have never personally had to remove an online article, this study will introduce hypothetical scenarios to help understand the decision-making process as well as include the severe alteration of published articles.

Your participation is voluntary and you may opt out at any time. I shall be very grateful, however, if you choose to complete the interview, which will only take about 45 to 60 minutes. The interview will be audiotaped with your consent.

Your responses will be confidential and will not be linked to any identifiable information in the finished thesis. Your name will be part of a master key that will be saved on a secure laptop, and no one else will have access to it except myself. Your name and any identifiable information including your newspaper name will not appear in the final research paper.

Your participation should not cause you any risks greater than those encountered in ordinary conversations about similar topics in everyday life. If you have any questions about this interview, please contact me at (561) 951-0821 and npbkf@mail.missouri.edu 
or, anonymously if you wish, the University of Missouri's Institutional Review Board at (573) 882-9585 or through their email at umcresearchcirb@ missouri.edu.

I really appreciate your time and consideration for participating in this interview.

If you are willing to take part, please contact me via email at your earliest convenience.

Thank you.

Respectfully Yours,

Nina Pantic

(561) 951-0821 


\section{APPENDIX B: Interview questions}

The semi-structured interviews included a set of questions to loosely guide the answers and conversation. The questions included:

1. What is your role in choosing what content gets published and what does not? (Who makes the final decision in publishing and changing published articles?)

2. Have you ever had to deal with a story that called for unpublishing or severe alteration (such as name changes, removing large sections, unpublishing a story temporarily, etc.)? If yes, how was the decision made? Did you consult with others? Was there protocol to follow?

3. Does your method (real or hypothetical) of dealing with unpublishing requests satisfy your newspaper staff and the complainer?

4. Do you work closely with a lawyer, or have a lawyer to consult with?

5. How aware are you and your staff of legal repercussions?

6. What is your course of action if there was a threat of a lawsuit associated with a published article?

7. What is your personal experience with liabilities and published stories?

8. How do outside pressures influence your publishing or unpublishing decisions? (What are some of these outside pressures?)

9. How would you respond to and deal with scenarios 1, 2, 3 and 4 ? 


\section{APPENDIX C: Editors Table}

\begin{tabular}{|l|c|c|}
\hline Editor & $\begin{array}{l}\text { Years of experience (at the } \\
\text { particular newspaper) }\end{array}$ & Newspaper daily circulation \\
\hline 1 & 1.5 & 220,000 \\
\hline 2 & 20 & 300,000 \\
\hline 3 & 3 & 170,000 \\
\hline 4 & 30 & $2,400,000$ \\
\hline 5 & 31 & 55,000 \\
\hline 6 & 5 & 80,000 \\
\hline 7 & 17 & 170,000 \\
\hline 8 & 5 & $<50,000$ \\
\hline 9 & 10 & 450,000 \\
\hline Kathy English & 7 & 380,000 \\
\hline
\end{tabular}

